\title{
Kentsel Peyzajlarda Yol Kenarı Yeşil Alanların Kent Ekosistemi Çerçevesinde Değerlendirilmesi
}

\author{
Gül Aslı Aksu ${ }^{*}$ \\ 1* Kastamonu Üniversitesi, Mühendislik ve Mimarlık Fakültesi, Peyzaj Mimarlı̆̆ı Bölümü (ORCID: 0000-0002-6847-6182), gaaksu@kastamonu.edu.tr
}

(İlk Geliş Tarihi 28 Mayıs 2021 ve Kabul Tarihi 15 Ağustos 2021)

(DOI: $10.31590 /$ ejosat.944343)

\begin{abstract}
ATIF/REFERENCE: Aksu, G.A., (2021). Kentsel Peyzajlarda Yol Kenarı Yeşil Alanların Kent Ekosistemi Çerçevesinde Değerlendirilmesi. Avrupa Bilim ve Teknoloji Dergisi, (25), 736-748.

$\ddot{\mathbf{O} z}$

Kentleşme sürecinin yoğun olarak yaşandığı kent ekosistemlerinde birçok döngü sekteye uğramaktadır. Yeşil alan sisteminin bozulmasına bağlı olarak, kentsel 1sı adası oluşumları artmakta, yağmur suları hızla yüzeysel akışa geçmekte, yapay topoğrafyaya bağlı olarak suni mikro-iklimsel oluşumlar (rüzgar - gölge kanyonu oluşumu v.b.) görülmekte, havadaki partikül madde ve emisyon oranları yükselmektedir.

Kentsel peyzajlarda, meydana gelen bu değişimleri kontrol altında tutmanın en önemli yollarından bir tanesi, yeşil alan sisteminin devamlılığını sağlamaktır. Kent ortamında yol ağlarına eşlik eden yeşil alanlar, yeşil sistem içerisinde hat boyunca etkili olarak, yeşil üniteleri birbirine bağlayıcı bir karaktere sahiptir. Bu yapılarıyla hem yeşil sistemi tamamlayıcı hem yol ağların sebep olduğu zararlı etkileri frenleyici hem de bazı canlılar için yaşam ortamı teşkil edici özelliklere sahiptirler. Buna karşılık, planlama, tasarım ve yönetim kararlarında, yaşam kalitesi ve kentsel ekosisteme sağladıkları katkı bakımından göz ardı edilmektedir.

Bu makalede İstanbul, Beşiktaş İlçesi yeşil alan sistemine ait yol kenarı yeşil alanlar, peyzaj ekolojisi çerçevesinde ünite-koridormatris yaklaşımına göre ele alınıp sürdürülebilirlik açısından değerlendirilmiştir. Bu amaçla, öncelikle peyzaj ve sınıf düzeyi peyzaj metrikleri yardımıyla peyzaj paterni incelenmiştir. Peyzaj düzeyi metrikler konumsal hale getirilerek haritalanmıştır. Sonra örnek bir alan üzerinde yol kenarı yeşil alanların ekolojik fonksiyonları değerlendirilmiştir. Elde edilen bulgular kent içi yeşil sistem, ekolojik, fonksiyonel ve estetik bakış açılarına göre yorumlanıp öneriler getirilmiştir.
\end{abstract}

Anahtar Kelimeler: Yol kenarı yeşil alan, Peyzaj ekolojisi, Kentsel yeşil alan sistemi, Peyzaj planlama, Peyzaj metrikleri.

\section{Evaluation of Roadside Green Areas in Urban Landscapes in the Framework of Urban Ecosystem}

\begin{abstract}
Due to intense urbanization pressure, many ecological cycles are disrupted in the cities. The deterioration of the green network increases urban heat island effects, rainwater rapidly passes to runoff, artificial micro-climatic formations (wind-shade canyons, etc.) are seen depending on artificial topography, while particulate matter and emission rates rise.

One of the most important ways to keep these changes in urban landscapes under control is to ensure the continuity of the green network. Roadside green areas that are accompanying road networks in the urban environment and through their linear structure, have a binding character between green units in the green system. These structures are important parts of the green system by absorbing the negative effects of roads and constituting habitats for some living creatures. On the other hand, their contribution to the urban ecosystem in terms of the quality of life, planning, design, and management decisions has been ignored.

In this article, the roadside green areas belonging to the green network of Beşiktaş District of Istanbul are evaluated according to the unit-corridor-matrix approach within the framework of landscape ecology and in terms of sustainability. For this purpose, firstly, landscape pattern was examined by using landscape and class-level landscape metrics. Landscape-level metrics were mapped. Then, the ecological functions of the roadside green areas on a sample area were evaluated. The obtained findings were interpreted according to the urban green system, ecological, functional, and aesthetic perspectives, and suggestions were made.
\end{abstract}

Keywords: Roadside green area, Landscape ecology, Urban green network, Landscape planning, Landscape metrics

*Sorumlu Yazar: gaaksu@kastamonu.edu.tr / aslibozbay@yahoo.de 


\section{Giriş}

Kentleşme, peyzaj desenlerine mekânsal dönüşüm süreçleri şeklinde etki ederken, peyzaj fonksiyonları da başta iklim, toprak, rölyef, biyolojik yapı olmak üzere değişime uğramakta, hatta etkinin boyutuna bağlı olarak geri dönüşümü çok zor olan bozulmalara maruz kalmaktadır (Forman, 2008). Kentleşmenin etkisiyle alanların su rejimi bozulmakta, doğal rölyef değişmekte, doğal toprak özellikleri kaybolmakta, kentsel 1s1 adası oluşumları görülmektedir. Peyzaj desenindeki ve fonksiyonundaki değişim, bölgesel ölçekte yeşil alan sistemlerinin bozulmasından başlayıp, detayda biyotopların yok olmasına varıncaya kadar farklı neticeler doğurmaktadır.

Kentleşme, insan ve yap1 birimi yoğunluğunun belli alanlarda artması ve dişa doğru yayılmasıdır. Dünya nüfusunun yarısı, yoğunlaşma bölgeleri olan şehirlerde toplanmaktadır (Forman, 2014). Şehirlerde ve çevrelerinde meydana gelen bu yoğunlaşmanın neticesinde, sürdürülebilir arazi kullanımı en önemli problem olarak ortaya çıkmakta, araziler seri bir şekilde mekânsal dönüşüm süreçlerine maruz kalmaktadır (Forman, 1995). Teknoloji ve endüstrinin gelişmesiyle birlikte, hızlı nüfus artışının bir sonucu olarak ekosistemdeki insan baskısı artmış ve doğal çevreler yok olmaya ve yenilenebilir gücünü kaybetmeye yüz tutmuştur. Kentsel alanlardaki hızlı yapısal değişimler, yeşil alanların azalmasına ve geri planda kalmasına sebep olmuştur (Hergül ve Göker, 2020).

İnsan etkisiyle meydana getirilen kentsel ekosistemler tamamen doğallıktan uzaklaşmıştır; yağmur damlacıkları toprakla buluşmadan asfalt yollardan kanalizasyonlara karışmakta, fabrikalardan çıkan zehirli atık sular bütün akarsuların bileşimini değiştirmekte, topraklar asit yağışlarla zehirlenmekte, nefes aldığımız havanın gaz bileşimi değiştirilerek “doğallık”tan uzak yapay ekosistemler yaratılmıştır ve yaratılmaktadır (Çepel, 2006). Başta yüzeylerin geçirimsiz yapısal yüzeylerle kaplanmasından ve özellikle yol ağlarına bağlı olarak partikül madde ve emisyon oranlarının artarak atmosferde yoğunlaşmasından kaynaklanan "kent iklimi”, daha yüksek hava ve yüzey sıcaklıkları, 1şıma dengesinde bozulmalar, düşük rutubet değerleri ve çok çeşitli kaynaklardan türeyen kirleticilerin birikmesi gibi etkilere sebep olan kısıtlı atmosferik değişimlere sahiptir (Kuttler, 2008). Kent koşullarının değişmesi, genelde çevre kalitesinin bozulmasına sebep olmakta ve sağlık sorunları meydana getirmektedir (Çepel, 1994).

Enerji ve madde tüketiminin dügüum noktaları olarak kentler, küresel ekolojik tahribatı hızlandırmaktadırlar (Rees ve Wackernagel, 2008). İklim koşulları ve yüzey örtü tipine bağlı olarak, kent dokusu tarafından mikro ve mezo ölçekte isı adaları üretilebilmektedir (Oke, 1976). Özellikle kent koşullarında mikroklimatik koşullar ile yapay yüzeyler arasındaki ilişkilerin anlaşılması, sürdürülebilir tasarım anlayışına önemli katkılar sağlayacaktır (Erell, Pearlmutter ve Williamson, 2011). Yapılaşma yoğunluğunun arttığı bölgelerde yüzeyin kaplı olduğu yapısal malzemenin türü ve niteliğine bağlı olarak güneş ışınları gün boyunca emilip depolanır ve gün batımından sonra atmosfere verilir (Gartland, 2008).

İstanbul gibi nüfus yoğunluğunun fazla olduğu şehirlerde, kent peyzajında strüktürel olarak meydana gelen değişim, ekosistem döngülerini bozacak düzeye ulaşmaktadır. Arazi hızla yapaylaşmakta, yapılaşmaya bağlı olarak meydana gelen yapay topoğrafya, mikro ölçekte iklimi değiştirmekte, yüzeysel akışın artmasina sebep olmaktadır.

İstanbul'un Anadolu Yakası kapsamında yapılan araştırmaya göre 1987-2001 yılları arasındaki 14 yıllık dönemde, yeşil alan oranının \%66'dan \%58,69'a düştüğü, yapay yüzey oranının ise \%4,1'den \%12,64'e çıktığı görülmektedir (Musaoğlu vd., 2004). İstanbul Sarıyer İlçesi ile ilgili yapılan bir araştırmada 1997 2010 yılları arasında 13 yıllık bir zaman diliminde arazi örtüsün \%13'ünün yeşilden yapaya dönüştüğü tespit edilmiştir (Aksu, 2012). Araştırma alanının yarı kırsal yarı kentsel bir karakter sergilemesine karşılık, 2010 yılı bulgularına göre, \%3 oranında tarım alanı, $\% 1$ oranında su yüzeyi, $\% 33$ oranında yapay yüzey ve $\% 63$ oranında orman alanı ve yarı doğal yüzey tespit edilmiştir (Aksu ve Küçük, 2020). Sarıyer ilçesi ile Eyüp ve Şişli ilçelerinin bir kısmını kapsayan çalışmada ise yolların, yeşil alan bütünlüğünü en fazla parçalayan ve peyzaj devamlılığını olumsuz etkileyen yapılaşmış alan tipi olduğu tespit edilmiştir (Kirca et al., 2015)

Kullanım yoğunluğu ve kullanıcı profili, kullanım öncelikleri ve bunların zaman içerisindeki değişimi hakkında önemli ipuçları barndırmaktadır ve bu sayede peyzajların bütüncül bir bakış açısıyla değerlendirilebilmesine, biyolojik çeşitliliği korumaya ve geliştirmeye yönelik gerçekçi bir bakış açısının oluşturulabilmesine imkân tanımaktadır (Suri, 2018; Suri, 2019). Örnekleri verilen araştırmalardan elde edilen rakamsal bulgularla birlikte İstanbul, 2017 y1lı itibariyle 15.029.231 kişi olarak resmi kayıtlara geçen nüfusuyla, kentleşme sürecinin çok yoğun ve süratli seyrettiği bir şehir olarak dikkat çekmektedir (TÜİK, 2017). Bu nüfus yoğunluğu yeşil alan sistemi üzerindeki baskının başlıca sebebidir.

Özellikle doğaldan yapaya doğru hızlı bir dönüşüm süreci içerisinde olan metropoliten alanlardaki bu değişimlerin hassasiyetle ele alınması ve kent ekosistemini oluşturan bileşenlerin bütüncül bir sistem algısıyla değerlendirilmesi gerekmektedir.

Peyzaj Ekolojisi, insanın mekânsal desen üzerindeki etkilerinin ortaya konmasını sağlayan etkili bir çerçevedir. Peyzaj ekolojisi mekânsal heterojenliğe ve desen-süreç ilişkisine odaklanır ve peyzaj strüktürünün karakterini, değişim dinamiklerini ve insan etkilerini açıklamaya çalışır.

Özellikle kentsel peyzajlarda yeşil alanların önemli işlevleri söz konusudur:

- Doğanın adım taşlarıdırlar. $\mathrm{Bu}$ yapılarıyla kentsel yeşil sistemi, civardaki doğal sistemlerle ilişkilendirirler.

- Rekreasyonel amaçlara hizmet ederler.

- Mikroiklim koşullarının düzenlenmesine katkı sağlarlar.

- Partikül madde, emisyon, gürültü gibi olumsuz etkileri dengelerler.

- Canlılar için yaşamsal öneme sahiptirler, besin ve barınma ortamı sağlarlar.

- Ekolojik değeri yüksek olan yeşil koridorlar, yaşama ortamları arasındaki akışı sağlar. 
- Özellikle kentsel alanlarda, ekosistem döngüleri açısından önemli görevler üstlenen yeşil alanların, insanların yaşam kalitesini artırmak adına da önemli işlevlere sahip olduğu görülmektedir.

Daha birçok faydası sayılabilecek olan yeşil alanların bir sistem algısı içerisinde değerlendirilmesi, peyzaj fonksiyonuna ve strüktürüne yönelik önemli bilgiler vermektedir. Bu anlamda yeşil alanlar başlı başına peyzajın önemli indikatörleridir (göstergeleridir).

Peyzaj ekolojisi strüktür, fonksiyon ve değişim olmak üzere üç mekanizmaya odaklanmaktadır. Bu mekanizma içerisinde çizgisel yapıdaki koridorlar, bağlayıcı özellikleriyle ön plana çıkmaktadır. Koridorlar, peyzaj strüktürünün ekolojik açıdan devamlılığının sağlanabilmesi için son derece önemlidir (Forman ve Godron, 1986). Özellikle yukarıda ifade edilen baskılara maruz kalan yeşil alan sistemlerinin devamlılığının sağlanması, hassas dengeler üzerine kurulu olan kent ekosistemi açısından önem taşımaktadır. Hellmund ve Smith (2006), peyzaj içerisinde ekolojik açıdan bağlayıcı nitelik taşıyan çizgisel karakterdeki yeşil ünitelerin çok yönlü faydalarına değinmekte ve yeşil sistem içerisindeki bağlantısallığın önemini vurgulamaktadır. Bentrup (2008) da yeşil sistem içerisinde yeşil alanların birbiriyle olan ilişkisi ve bağlantılarının, biyolojik çeşitlilik ve doğa koruma açısından önemini, konuyla ilgili öncü çalışmalar rehberliğinde tartışmaktadır. Şekil 1a, ayrı yeşil ünitelerin birbirine farklı tiplerde yaklaşma şekline göre bağlantısallık düzeylerini göstermektedir. Şekildeki ilişkiler incelendiğinde, koridorlarla kurulan bağlantının kamalarla yaklaşmaya göre daha kuvvetli olduğu; kamalarla yaklaşma şeklinde kurulan bağlantının ise adım taşlarıyla kurulan bağlantıya göre daha güçlü olduğu anlaşılmaktadır.

Yeşil koridorlar ve bağlantı alternatifleri ne kadar artırılırsa, yeşil sistem o kadar stabil hale gelmektedir (Şekil 1b). Böylelikle herhangi bir etkenle, bağlantılardan birinde meydana gelebilecek zayiat, diğer bağlantı tipleri tarafindan telafi edilebilmektedir.

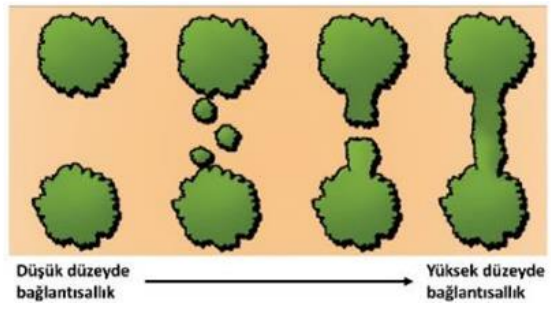

$-a-$

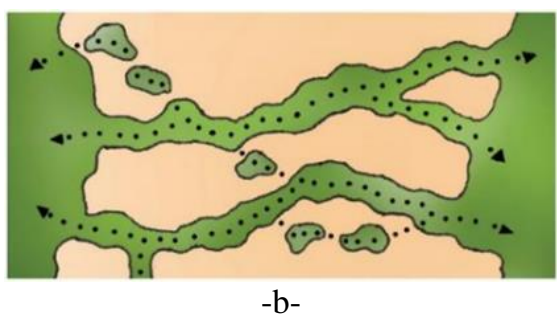

Şekil 1. (a) Yeşil ünitelerin birbirlerine farklı tiplerdeki yaklaşma şekline göre kurulan bağlantısallık düzeyleri. (b) Yeşil üniteler arasındaki bağlar ne kadar fazla alternatifli olursa, yeşil sistemin sürdürülebilirliğine olumlu yönde katkı sağlamaktadır (Bentrup, 2008'den uyarlanmıştır).
Yeşil üniteler arasındaki zayıf bağlantılarda yaşanabilecek zayiatlar, telafisi mümkün olmayan kopmalara sebep olabilmektedir (Şekil 2). Bu durumda yeşil sistem içerisindeki akışlar da sekteye uğramaktadır.

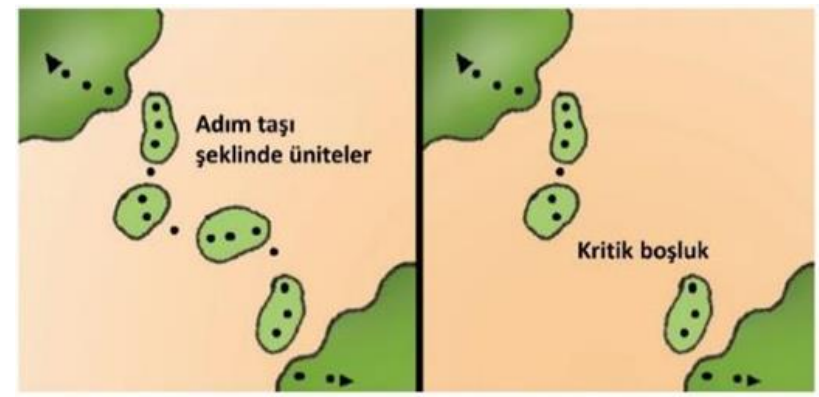

Şekil 2. Yeşil sistemdeki üniteler arasındaki bağlantıların kritik düzeyde kopmass sonucunda, yeşil sistem sekteye uğrayabilmektedir (Bentrup, 2008'den uyarlanmıştır).

Ekosistemler için önem arz eden başlıca süreçler, madde dolaşımı ve enerji akımıdır. $\mathrm{Bu}$ iki önemli sürecin sürdürülebilirliği ve dengesi biyolojik çeşitliliğin korunmasına bağlıdır (Çepel, 2003). Kent ekosistemlerinde daha hassas dengeler ve eşik değerleri söz konusu olduğu için biyolojik çeşitliliği destekleyecek yapıların önemi de artmaktadır.

Kent ekosistemi içerisinde, çizgisel karakterleri itibariyle, ulaşım ağlarının olumsuz etkilerine hat boyu kendini siper eden ve bu düzenleyici etkinin devamlılığına katkı sağlayan en önemli sistemler, yol ağlarına eşlik eden yeşil alanlardır. Bu alanların, kent ekosistemi içerisinde yeşil üniteleri bağlama, özellikle kuşlar ve kelebekler gibi uçabilen canlılar için yaşama ortamı teşkil etme, bununla birlikte yol ağlarının olumsuz etkilerini dengeleme gibi hayati işlevleri vardır. Bu tip alanların, varlığını sürdürebildiği kent ortamlarında hassasiyetle değerlendirilmesi, kent ekosistemini destekleyecek nitelikte tasarlanması, yeşil yol ve koridor tasarımlarına öncülük edecek yeşil sistem unsurları olarak algılanması gerekmektedir. Bitki türü tercihlerinin, düzenleme prensiplerinin bu desteği sağlayacak şekilde kurgulanması gerekmektedir. Bu yeşil sistemler aynı zamanda yol ağlarının emisyon, toz, gürültü gibi olumsuz etkilerini filtrelemekte, yapılarla yol ağları arasında tampon görevi görmektedir. Yeşil sistemin önemli bileşenleri olan yol kenarı yeşil alanlar, bir yandan çizgisel karaktere sahip yollara hat boyunca eşlik ederken, diğer yandan kent ekosistemindeki diğer noktasal yapıdaki yeşil üniteleri birbirine bağlamakta ve bu sayede tür hareketliliğini ve biyolojik çeşitliliği teşvik edebilmektedir. Bununla birlikte çizgisel karakterleri sayesinde kentsel yeşil sistem içerisine nüfuz ederek kentsel 1s1 adası oluşumu gibi mikro iklimsel olumsuzlukların etkilerini kırmaktadır. Yukarıda sayılan faydaları ile kent ekosisteminin önemli işlevsel bileşenleri olan yol kenarı yeşil alanlar, aynı zamanda estetik açıdan da önem taşımaktadır.

19. yy'ın sonlarından itibaren kent için yeşil sistemi desteklemek ve kent ekosistemini düzenlemek üzere "Yeșil Yol" (greenway) kavramının Amerika'da tasarım literatürüne girdiği görülmektedir (Ahern, 2004). Avrupa'da da özellikle 20. yy'in ortalarından itibaren peyzaj ekolojsi kavramı; peyzaj strüktürü, tür hareketliliği ve biyolojik çeşitlilik gibi araştırmaların temel çerçevesini oluşturmuş, akabinde ekolojik ağlarla ilgili çalışmalar yapılmaya başlanmıştır (Jongman ve Pungetti, 2004). 
Ekolojik ağların peyzaj ekolojisi çerçevesinde nicel olarak, ünite - koridor - mozaik mantığı ile değerlendirilmesi, kent ekosisteminin sürdürülebilirliği açısından da önem taşımaktadır (Jongman, 2004). Günümüzde özellikle yoğun kentleşme baskısı altındaki metropollerde kent içi yeşil sistemin hem peyzaj strüktürü hem de peyzaj fonksiyonu açısından değerlendirilmesi, yeniden yapılandırılması ve tasarlanması kent planlamasının önemli konularından birisi haline gelmiştir (Forman, 2014).

Kent ekosistemi içerisinde üstlendikleri bağlayıcı ve tampon rolleri itibariyle, yol ağlarına eşlik eden yeşil alanların öncelikli olarak ekolojik faydaları açısından değerlendirilmesi gerekmektedir. $\mathrm{Bu}$ araştırmada, yol kenarı yeşil alanların kent ekosistemi açısından önemi ve peyzaj strüktüründeki yeri, İstanbul Beşiktaş İlçesi örneğinde değerlendirilip tartışılmıştır. $\mathrm{Bu}$ maksatla öncelikle patern analizi yardımıyla mevcut yeşil sistem ortaya konmuş, peyzaj metrikleri yardımıyla nicel olarak değerlendirilmiştir. Sonrasında yol kenarı yeşil alanların bu mevcut yeşil sistem içerisindeki konumu ve fonksiyonları tartışılmıştır. Yapısal yüzeylerin baskın hale geldiği ve yol kenarı yeşil alanların sekteye uğradığı kısımlarda bağlantısallığın sürdürülebilmesi adına yeşil çatı-cephe sistemlerinin, yağmur bahçelerinin ve dikey bahçelerin kullanım ve tercih olanakları ile ilgili öneriler getirilmiştir.

\section{Materyal ve Metot}

\subsection{Materyal}

Araştırma alanı olan Beşiktaş, İstanbul'un Avrupa yakasında $41^{\circ} 02^{\prime} 31^{\prime \prime}$ kuzey enlemleri ile $29^{\circ} 00^{\prime} 26^{\prime \prime}$ doğu boylamları arasında yer almaktadır. Beşiktaş idari olarak İstanbul Büyükşehir'e bağlı bir ilçedir. Kuzey'de Sarıyer; doğuda ve güneyde İstanbul Boğazı; batıda ise Şişli, Kağıthane ve Beyoğlu ilçeleriyle komşu olan araştırma alanı $18.22 \mathrm{~km}^{2}$ yüzölçümüne sahiptir (Şekil 3).

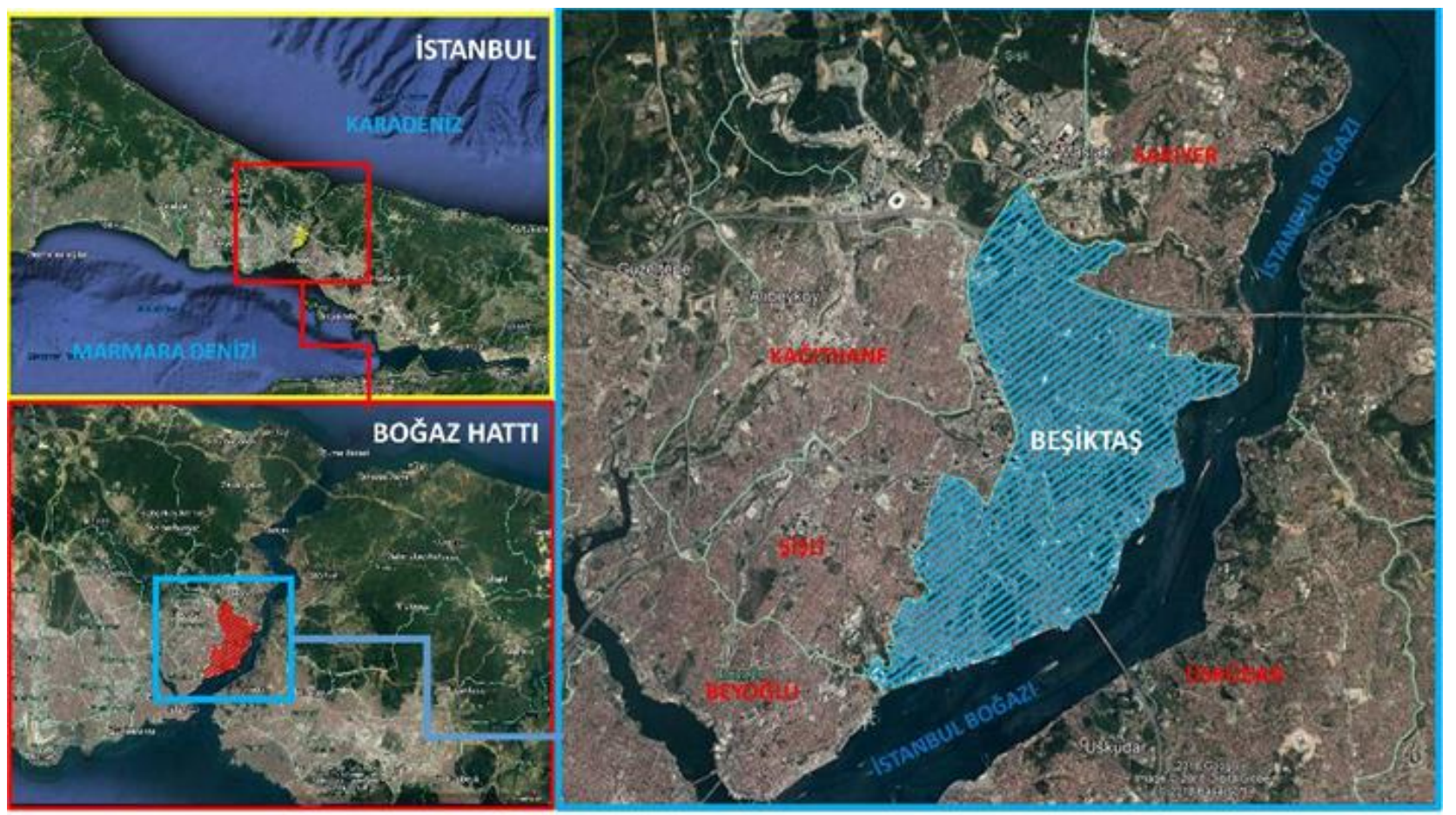

Şekil 3. Araştırma alanı Beşiktaş, İstanbul İline bağlı, yoğun kentleşme baskısı altında olan bir ilçedir. (KAYNAK: Google Earth, 2018)

Beşiktaş hem İstanbul gibi bir metropolün merkezinde yer alması hem de kara ve deniz ulaşım alternatiflerine sahip olması ve bu bakımdan aynı zamanda bir transfer merkezi niteliği taşıması açısından dikkat çekmektedir.

İstanbul Beşiktaş İlçesi kapsamında yapılan araştırmaya göre, arazi örtüsünün \%61,63'lük kısmı yapay yüzeylerden, $\% 0,34$ 'lük kısmı su yüzeylerinden ve ancak \%38.04'lük kısmı yeşil alanlardan ibarettir. $\mathrm{Bu}$ yeşil alan oranının içerisinde yol kenarı yeşil alanlar \%4,73'lük bir orana sahiptir. Buna karşılık yol ağları, \%22,85 gibi bir oranla ön plana çıkan yapılardır.

Araştırma alanı içerisinde refüjleri peyzaj fonksiyonu ve peyzaj strüktürü açısından değerlendirmek üzere bir test alanı belirlenmiştir. Belirlenen test alanı, çok yoğun bir trafik akışına sahip olan 1. Köprü bağlantı yoluna Balmumcu mevkiinde eşlik eden yeşil alandır (Şekil 7).

\subsection{Metot}

Darmstad, Olson ve Forman (1996)'a göre modern peyzaj ekolojisi, ünite-mozaik paradigmasına (patch - mosaic paradigm) dayanmaktadır. Bu konsept doğrultusunda peyzajlar, birbirinden farklı ünitelerin mozaikleri olarak ele alınmaktadır. Araştırma alanının yeşil sistem değerlendirmesi, peyzaj patern analizinden elde edilen nicel bulguların, bütüncül bir bakış açısıyla yorumlanması sonucunda gerçekleştirilmiştir.

McGarigal (2002)'a göre Peyzaj Patern Analizi'nin amac1, ünite mozaiğinin bileşimini ve mekânsal düzenini karakterize etmektir ve bu maksatla birçok metrik geliştirilmiştir.

Araştırmada öncelikle Forman ve Godron (1986) ve Forman (1995) tarafindan tanımlanan ünite-koridor-matris modelini referans alan bir peyzaj patern analizi yapılmış, yeşil alan sistemini meydana getiren strüktürel unsurlar sınıf ve peyzaj düzeyi metrikler yardımıyla yorumlanmıştır. Metriklerin hesabı için McGarigal, Cushman ve Ene (2015) tarafindan tasarlanan 
Fragstats v4.2.1 yazılımından yararlanılmıştır. Peyzaj düzeyi metrikler, yazılımin "Hareketli Pencere" (Moving Window) modülü yardımıyla konumsal hale getirilip harita üzerinde görselleştirilmiştir. Hareketli pencere analizinde $100 \mathrm{~m}$. yarıçaplı dairesel pencere tercih edilmiştir. Patern analizine tabi tutulan peyzaj ve sınıf düzeyi metrikler Tablo 1'de verilmiştir.

Tablo 1. McGarigal vd. (2015) ve McGarigal (2002)'ye göre seçilen peyzaj ve sınıf düzeyi metrikler.

\begin{tabular}{|c|c|c|c|}
\hline Metriğin Türkçe Adı & Metriğin İngilizce Adı & Kisaltma & Tanımlama \\
\hline Sinıf Alanı & Class Area & CA (ha) & Sinıfin toplam alanı \\
\hline Peyzaj Yüzdesi & Percentage of Landscape & PLAND (\%) & Sinıfin toplam alandaki yüzdesi \\
\hline Ünite yoğunluğu & Patch Density & PD (n/100ha) & Birim alana düşen ünite sayısı \\
\hline Ünite Sayısı & Number of Patches & NP & Söz konusu sınıfin veya peyzajın ünite sayısı \\
\hline En Büyük Ünite İndeksi & Largest Patch Index & LPI $(\%)$ & En büyük ünitenin peyzajdaki yüzdesi \\
\hline Etkili A $\breve{g}$ Boyutu & Effective Mesh Size & MESH (ha) & $\begin{array}{l}\text { Sınıfa ait toplam ünite alanının toplam peyzaja } \\
\text { oranlanmasıyla elde edilen alandır (ha) }\end{array}$ \\
\hline Peyzaj Şekil İndeksi & Landscape Shape Index & LSI & $\begin{array}{l}\text { Maksimum düzeyde kümelenmiş sınıfın toplam kenar } \\
\text { uzunluğunun minimum kenar uzunluğuna bölümü (hücre } \\
\text { yüzeyi sayısı olarak) }\end{array}$ \\
\hline $\begin{array}{l}\text { Ünite Alanı (Alan ağırlıklı } \\
\text { ortalama) }\end{array}$ & $\begin{array}{l}\text { Patch Area-Area-Weighted } \\
\text { Mean }\end{array}$ & $\begin{array}{l}\text { AREA_AM } \\
\text { (ha) }\end{array}$ & $\begin{array}{l}\text { Bir sınıfın veya peyzajın tüm ünitelerine genellenmiş ayrı } \\
\text { ünitelerinin alan ağırlıklı ortalama büyüklüğü (Leitão vd., } \\
\text { 2006) }\end{array}$ \\
\hline $\begin{array}{l}\text { En yakın komşunun öklit } \\
\text { mesafesi (Alan ağırlıklı } \\
\text { ortalama) }\end{array}$ & $\begin{array}{l}\text { Euclidean Nearest-Neighbor } \\
\text { Distance-Area-Weighted Mean }\end{array}$ & ENN_AM (m) & $\begin{array}{l}\text { Hedef ünite ile aynı sınıfa ait en yakın komşusu arasındaki } \\
\text { en kısa mesafenin alan ağırlıklı ortalaması }\end{array}$ \\
\hline Kümelenme İndeksi & Aggregation Index & AI $(\%)$ & Ünitelerin peyzaj içerisindeki kümelenemelerinin derecesi \\
\hline $\begin{array}{l}\text { Simpson'un Çeşitlilik } \\
\text { İndeksi }\end{array}$ & Simpson's Diversity Index & SIDI & $\begin{array}{l}\text { Her bir ünite tipinin karesinin orantısal çeşitliliğinin } \\
\text { toplamının 1'den farkdır. }\end{array}$ \\
\hline
\end{tabular}

Özellikle Yol ve Yol Kenarı Yeşil Alan sınıflarının yorumlanmasına öncelik verilmiştir. Bunun için bu iki sınıfa ait metrik değerleri genel peyzaja ait bulgularla kıyaslanmış ve sınıflar arasındaki durumu tayin edebilmek üzere diğer sınıfların verileriyle karşılaştırılmıştır.

Patern analizinden elde edilen bilgi sentezlenerek, yol ağlarına eşlik eden yeşil alanların, yeşil sistem içerisindeki konumları da dikkate alınarak, peyzaj ekolojisi ve sürdürülebilir planlama çerçevesinde bütüncül bir değerlendirmesi yapılmıştır.

Kentsel yeşil alanlar, insan faaliyetlerinin kirlilik, gürültü, kentsel 1Sı adası oluşumu gibi olumsuz sonuçlarının etkisini frenler ya da tamamen ortadan kaldırırlar. Ancak kentsel peyzaj içerisinde lokal ve noktasal birer ada olarak kalmış yeşil ünitelerin bütüncül bir fayda sağlaması zordur. $\mathrm{Bu}$ nedenle araştırmada ulaşım ağlarına eşlik eden çizgisel karakterdeki yeşil alanlar, başta bağlayıcı etkileri dolayısıyla peyzaj deseninin önemli bileşenleri olarak peyzaj ekolojisi çerçevesinde değerlendirilmiştir. Örnek olarak seçilen alanda ayrıca arazi gözlemleri, rasgele zamanlarda gürültü düzeyi, partikül madde ve emisyon ölçümleri gerçekleştirilmiştir. Peyzaj strüktürü ve fonksiyonu bakımından ele alınan araştırma alanı ile ilgili son olarak, özellikle ulaşım sistemi ve ulaşım sistemine eşlik eden yeşil alanlar düzeyinde, sürdürülebilir planlama ve kentsel peyzaj tasarımı çerçevesinde öneriler sunulmuştur

\section{Araştırma Sonuçları ve Tartışma}

\subsection{Bulgular}

Beşiktaş Yeşil Alan Sistemi'nin başta kent ekosistemi ile ilgili olmak üzere, çok yönlü olarak değerlendirilebilmesini sağlayacak bulgular elde edilmiştir. "Yolların" ve "Yol Kenarı Yeşil Alanların" peyzaj paterni içerisindeki analitik değerlendirmesi, genel peyzaja ve diğer sinıflara göre, metrik değerleri üzerinden yapılmıştır. Peyzaj düzeyi hareketli pencere analizinden elde edilen haritalar yarı saydam hale getirilerek uydu görüntüsü ile çakıştırılmıştır. $\mathrm{Bu}$ sayede metrik yorumlamaları peyzaj genelindeki desenlerin dağılımına göre yapılabilmiştir.

\subsubsection{Peyzaj Düzeyi Analiz Bulgulart}

Seçilen Peyzaj düzeyi peyzaj metrikler Fragstats v4.2.1. yazılımının (McGarigal vd., 2015) "Hareketli Pencere" (Moving Window) modülünde analiz edilerek metrik sonuçları konumsal hale getirilmiştir (Şekil 4a-f). 


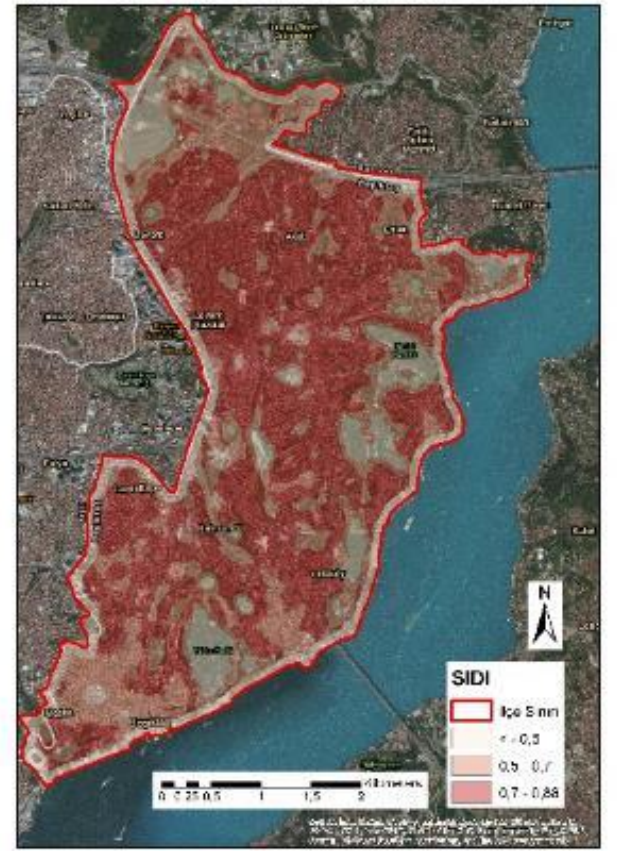

$-a-$

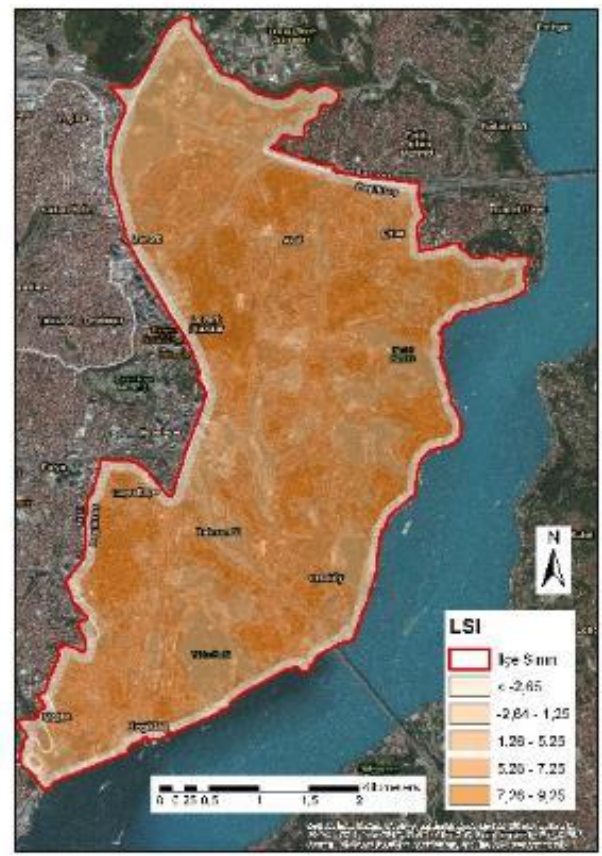

$-\mathrm{C}-$

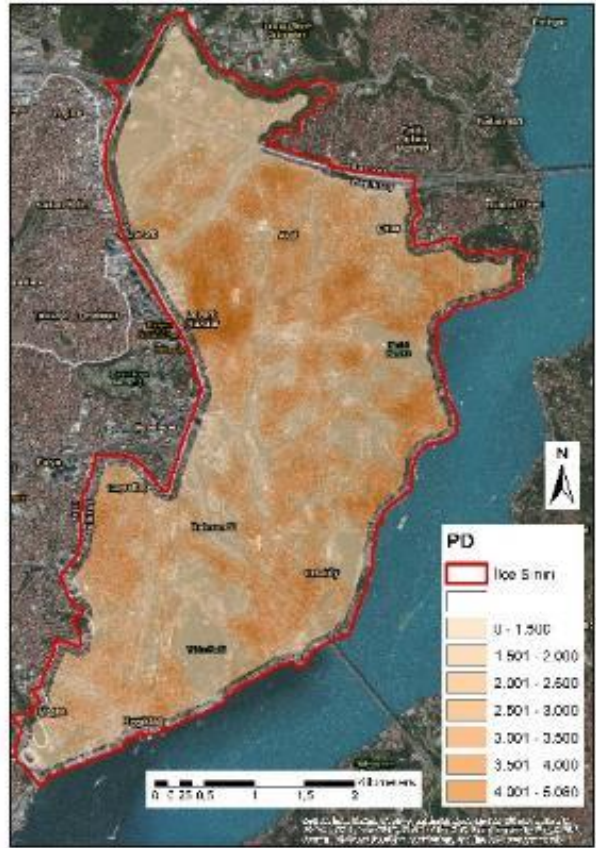

$-b-$

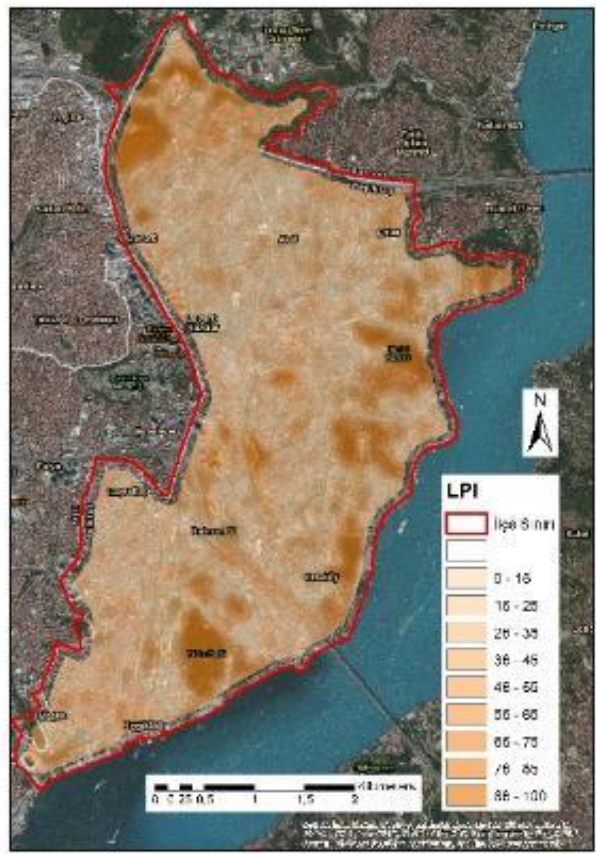

$-\mathrm{d}-$

Şekil 4. Peyzaj Düzeyi Hareketli Pencere (Moving Window) analiziyle konumsal hale getirilmiş peyzaj metrikleri. (a) SIDI sonucu (b) PD sописи (c) LSI sописи (d) LPI sonиси (e) ENN_AM sописи (f) AI sonиси.

SIDI sonuçları değerlendirildiğinde (Şekil 4a), çeşitlilik indeksinin yoğunlaştı̆̆ alanların daha ziyade yapı parsellerinin olduğu bölgelere denk geldiği görülmektedir. Ancak Türkali, Dikilitaş, Ortaköy gibi yapılaşma düzeyinin yüksek olduğu alanlarda, SIDI değerinin düştüğü gözlemlenmektedir. $\mathrm{Bu}$ kısımlarda yapısal yüzeylerin blok parçalar halinde bütünleşmesinin ve aralarda çok kısıtlı miktarda yeşil dokunun sokulmasına izin vermesinin etkisi olduğu düşünülmektedir. $\mathrm{Bu}$ etki, çeşitlilik değerini düşürmektedir. Özellikle birinci ve ikinci köprülerin ana arter niteliğindeki bağlantı yollarında da SIDI indeksinin düşük olduğu görülmektedir. Barbaros Bulvarı'nda SIDI indeksi ağırlıklı olarak en yüksek değerlere ulaşmaktadır. $\mathrm{Bu}$ arterde, köprü çevre yollarına kıyasla çeşitliliğin yüksek çıkmış olması, yola komşu olan alanlardaki doku farklılıklarından (yol ağaçları, farklı tipolojide yapı parselleri vb) kaynaklandığı düşünülmektedir. Yeşil alan tipleri incelendiğinde, özellikle korulara denk gelen kısımlarda SIDI değerinin düştüğü dikkat çekmektedir. Bu durum, koru alanlarının baskın ve homojen bir karakter sergilediğini düşündürmektedir. Koru alanlarının bu stabil yapısı yeşil alan sisteminde merkezi rol 
üstlenmeleri açısından sevindiricidir. Yollara blok halde eşlik eden yeşil alanlarda da SIDI değerinin düşük olması, bu alanların araç yollarının olumsuz etkilerini dengelemek bakımından ne kadar önemli olduğunu göstermektedir. Yapısal yüzeyler tarafından sekteye uğratıldıkları alanlarda, çeşitlilik arttığından, SIDI değeri hemen yükselmektedir.

PD değerinin daha çok yapısal alanlarda yoğunlaştığg fakat yapı parsellerinin blok halde birleştiği ve devamlılık arz ettiği alanlarda düştüğü görülmektedir (Şekil 4b). PD değeri düşük olan alanlar olarak yollar ve korular dikkat çekmektedir. $\mathrm{Bu}$ durum, iki sınıfa ait ünitelerin büyük ve blok parçalar halinde olduğunu göstermektedir.

LSI değeri blok halde ünitelerin kümelendiği alanlarda daha düşük çıkmıştır (Şekil 4c). Bu durum blok ünitelerin birleşerek geometriğe yakın bir şekilde sınır oluşturduklarını göstermektedir. Bu durum, yapısal yüzeyler için beklenen bir özellik olsa da özellikle büyük ve bütüncül ünitelere sahip olan koruların yoğunlaştığı alanlarında da LSI değerinin düşük çıkması, koruların doğal yapıda girintili çıkıntılı olan kenar özelliklerini terk ettiklerini göstermektedir. Bu durum biyolojik çeşitlilik açısından özellikle kenar alanları tercih eden türler açısından olumsuz şartlar meydana getirmektedir. Bunun dişında ana yol güzergahlarında da LSI değerinin düşük çıkması beklenen bir durum olmuştur. Bu yapı, yolların çizgisel bariyer etkisini teyit etmektedir.
LPI değerinin en yüksek olduğu alanların sahil hattındaki ve alanın en kuzeyindeki korulara denk gelmesi, sevindirici bir bulgu olmuştur (Şekil 4d). Bu durum özellikle yeşil sistem içerisindeki bağlantısallığın pekiştirilmesinde koru alanlarının merkezi bir rol üstleneceğini göstermektedir.

ENN_AM değerinin ana arterlere denk gelen kısımlarda yükseldiği görülmektedir (Şekil $4 \mathrm{e}$ ). $\mathrm{Bu}$ bulgu, blok halde peyzajı geçen yolların alan ağırlıklı ortalama bakımından birbirine uzak olarak konumlandığını göstermektedir.

AI değerleri özellikle korulara ve yollara eşlik eden yeşil alanlara ait ünitelerin belli bölgelerde kümelendiğini göstermektedir (Şekil 4f). Bu bölgeler, yeşil sistem içerisinde bağlantısallığın güçlendirilmesine öncelik verilmesi gereken, bütünleşmeye yatkın bölgelerdir.

\subsubsection{Sınıf Düzeyi Analiz Bulgulart}

Sınıf düzeyi peyzaj metrik değerleri Tablo 2'de görülmektedir. Araştırma alanındaki yapay yüzeyleri, "Sert Zemin", "Bina" ve "Yol" sınıfları oluşturmaktadır. Yeşil alan olarak ise "Park", "Mezarlık", "Koru", "Bahçe" ve "Yol Kenarı Yeşil Alan” sınıfları değerlendirilmiştir. Çok minimal bir peyzaj yüzdesine sahip olan "Su Yüzeyleri” ile ilgili metrik değerleri ise genel anlamda biyolojik çeşitliliğin, ekolojik ağların ve sınıflar arası ilişkilerin yorumlanmasına ışık tutmuştur.

Tablo 2. Sınıf Düzeyi peyzaj metrik değerleri arasında “Yol Ağlarının” ve "Yol Kenarı Yeşil Alanların” durumu.

\begin{tabular}{lrrrrrrrrr} 
Biyotop Tipi & CA & PLAND & NP & PD & LPI & LSI & AREA_AM & ENN_AM & MESH \\
\hline Yol & $\mathbf{4 1 6 , 4 9}$ & $\mathbf{2 2 , 8 5}$ & $\mathbf{5 . 2 5 8}$ & $\mathbf{2 8 8 , 5 2}$ & $\mathbf{1 9 , 1 6}$ & $\mathbf{1 3 0 , 4 4}$ & $\mathbf{2 9 2 , 7 4}$ & $\mathbf{2 , 4 4}$ & $\mathbf{6 6 , 9 0}$ \\
\hline Yapı & 391,51 & 21,48 & 14.214 & 779,95 & 0,27 & 143,66 & 0,24 & 4,60 & 0,05 \\
Sert Zemin & 315,10 & 17,29 & 15.389 & 844,42 & 0,28 & 201,60 & 0,72 & 3,17 & 0,13 \\
Bahçe & 280,54 & 15,39 & 6.212 & 340,86 & 0,85 & 106,99 & 2,09 & 5,09 & 0,32 \\
Yol Kenarı Y.A. & $\mathbf{8 6 , 1 2}$ & $\mathbf{4 , 7 3}$ & $\mathbf{5 8 3}$ & $\mathbf{3 1 , 9 9}$ & $\mathbf{1 , 3 1}$ & $\mathbf{3 3 , 6 8}$ & $\mathbf{7 , 7 6}$ & $\mathbf{7 , 1 6}$ & $\mathbf{0 , 3 7}$ \\
Park & 71,12 & 3,90 & 300 & 16,46 & 0,65 & 26,13 & 3,25 & 30,39 & 0,13 \\
Koru & 234,49 & 12,87 & 63 & 3,46 & 3,34 & 29,73 & 38,71 & 20,88 & 4,98 \\
Mezarlık & 20,97 & 1,15 & 11 & 0,60 & 0,30 & 4,82 & 3,79 & 99,20 & 0,04 \\
Su Yüzeyi & 6,11 & 0,34 & 630 & 34,57 & 0,05 & 27,45 & 0,18 & 45,47 & 0,01
\end{tabular}

Peyzaj düzeyi metrik bulgularına göre LPI değeri incelendiğinde "Yol" sınıfının LPI değeri ile aynı olduğu görülmektedir. Bu durum, peyzaj içerisinde blok halde yer alan Yol sınıfına ait ünitelerin, baskın olduğunu göstermektedir. Alansal olarak da en yüksek peyzaj yüzdesine $(\mathrm{PLAND}=22,8533)$ sahip olan yolların peyzajı domine ettiği anlaşılmaktadır (Şekil 5).

"Yol” sınıfının bütün ve büyük parçalardan oluştuğu, metrik değerlerinden anlaşılmaktadır. Bununla birlikte ünite sayısının $(\mathrm{NP}=5.258)$ yüksek olması, peyzaj içerisinde ne kadar baskın bir sınıf olduğuna işaret eden diğer bir göstergedir. Sınıf içerisindeki alan ağırlıklı ortalama değerini veren AREA_AM $(292,7406)$ metrik değeri de tüm peyzaj alanına göre ortalama alan büyüklügünü hesaplayan MESH $(66,9010)$ metriğine göre de bu sınıf en baskın sınıf konumundadır. Bu değerler tüm peyzaj düzeyindeki alan ağırlıklı ünite büyüklüğü değerinin (AREA_AM=72,9163) de çok üstündedir.

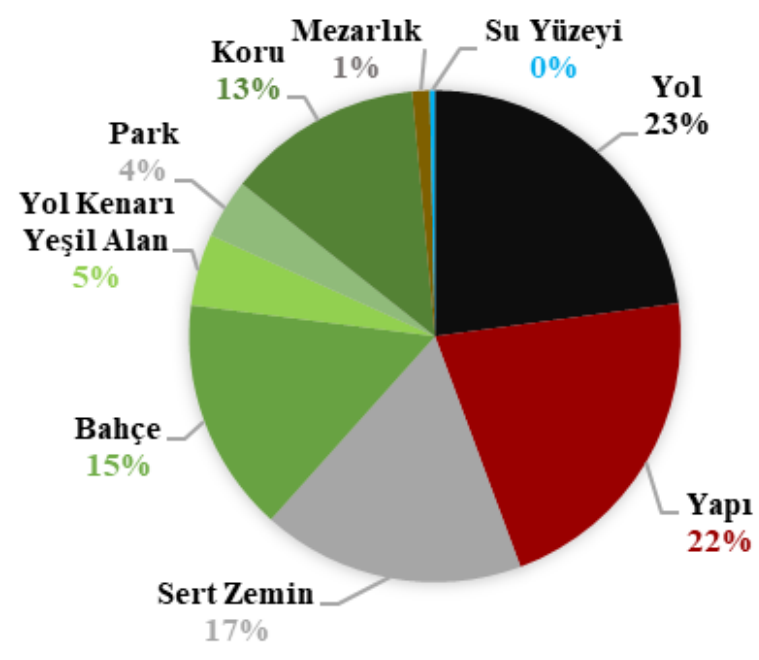

Şekil 5. Sınıflara göre Peyzaj Yüzdesi (PLAND) dăğlımları. 
Peyzaj düzeyinde ENN_AM değeri 8,3803 iken "Yol" sınıfinda bu değerin 2,4370'e düşmüş olması, bu sınıfa ait blok haldeki baskın ünitelerin birbirine ne kadar yakın olarak konumlandığını ve peyzaj ortalamasına göre çok daha yoğun bir yap1 oluşturduğunu göstermektedir. $\mathrm{Bu}$ nedenle yol ağları, biyotop olmanın ötesinde peyzaj içerisinde çizgisel karaktere sahip bariyerler olarak algılanmaktadır.

Farina (1998)'ya göre bir koridor, başka habitat tipleri tarafından çevrelenmiş, dar habitat şeridi olarak tanımlanabilir. Bitkiler ve hayvanlar, bir koridorda enine rahatlıkla hareket edebilirler. Ancak tür davranışındaki en büyük çeşitlilik, koridorlar boyunca mevcuttur. Bu nedenle enine çizgisel bariyer teşkil eden yapılar, tür davranışlarını olumsuz yönde en çok etkileyen yapılardır. Şekil 6.'de araştırma alanını enine ve boyuna parçalara ayıran başlıca ulaşım aksları görülmektedir.

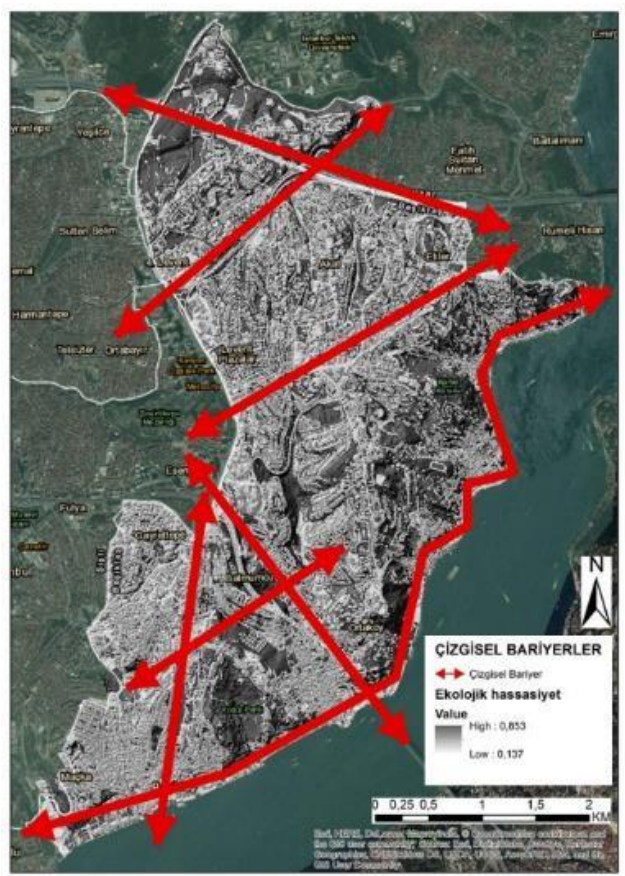

Şekil 6. Araştırma alanında çizgisel bariyer teşkil eden ulaşım aksları.

Kent peyzajı içerisinde rakamlara da yansıyan yolların bu baskın etkisi, çizgisel karakterdeki Yol Kenarı Yeşil Alanlar tarafindan hat boyunca dengelenebilmektedir. Ancak Yol Kenarı Yeşil Alan sınıfının peyzaj ve sınıf düzeyi metrik değerleri incelendiğinde, araştırma alanında bu sınıfın ne kadar yetersiz kaldığı anlaşılmaktadır. Başta peyzaj yüzdesi bakımından kıyaslandığında Yol Kenarı Yeşil Alanların \%5'lik oranla yol ağlarının çok gerisinde kaldığı görülmektedir. ENN_AM değerinin $(7,1610)$ yüksek çıkması, bu sınıfa ait ünitelerin birbirinden uzak kaldığını göstermektedir. NP (583) ve LPI $(1,3126)$ değerlerinin de bir hayli düşük çıkması, bu sınıfa ait az sayıdaki ünitenin geniş alanlara yayılamadığını göstermektedir. Ünite yoğunluğu değerinin $(\mathrm{PD}=31,9901)$ düşük çıkması da bu bulguyu desteklemektedir. LSI değerleri de Yol Kenarı Yeşil Alanların (LSI=33,6816) Yollara (LSI=130,4348) göre daha geometriğge yakın sınırlar arasında kaldığını göstermektedir. $\mathrm{Bu}$ değer peyzaj ortalamasının (LSI=141,0255) da çok altındadır. Geometrik bir karaktere sahip olmalarına rağmen yollara ait LSI değerinin bu kadar yüksek çıkmış olması da Yol sınıfını oluşturan ünitelerin birleşmek suretiyle kompleks bir şekil yapısına büründüğünü göstermektedir.

Yol Kenarı Yeşil Alanların diğer yeşil alan tipleriyle ilişkilerine bakıldığında Peyzaj içerisinde yeşil alan olarak hakimiyet kuran Bahçeler ve Korular dikkat çekmektedir (PLANDBahçe=15,40 PLANDKoru=12,87). Bahçelerin daha parçalı bir yap1 oluşturduğu NP ve PD değerlerinin yüksek oluşundan da anlaşılmaktadır. Buna karşılık korular daha bütünleşik parçalarla peyzaj içerisinde temsil edilmektedir. Yeşil alan kategorisi içerisinde koruların en yüksek en büyük ünite indeks değerine ( $\mathrm{LPI}=3,3352)$ sahip olması da bu bulguyu desteklemektedir. $\mathrm{Bu}$ bütünleşik yapı, koruların yeşil alan sisteminde merkezi bir rol üstlendiklerini göstermektedir. $\mathrm{Bu}$ yapıları nedeniyle kentsel peyzaj içerisinde yeşil sistemin devamlılığını sağlamak üzere yol kenarı yeşil alanlarla ilişkili hale getirilmeleri önem kazanmaktadır. Bahçeler, korulara nazaran daha küçük ünitelerle temsil edilseler de alansal olarak en fazla alan kaplayan yeşil alan sınıfidır. Bu sınıfta korulara göre daha küçük üniteler görülmektedir ancak üniteler arası, alan ağırlıklı ortalama mesafeye bakıldığında bahçelere ait ünitelerin korulara ait ünitelere göre birbirine daha yakın konumlandığ anlaşılmaktadır.

\subsubsection{Yeşil Alan Sistem Değerlendirmesine Yönelik Bulgular}

İstanbul Beşiktaş İlçesi özelinde yapılan patern analizi neticesinde, koru alanlarının yeşil sistem içerisinde merkezi bir rol üstlendiği tespit edilmiştir. Yolların peyzajı çizgisel bir karakterde bölen ve Forman (1995)'ın mekânsal dönüşüm süreçlerinden "Açımlama" (Dissection) şeklinde tanımladığı etkisini tolere etmek üzere, bu yollara eşlik eden yeşil alanların ne kadar önemli olduğu anlaşılmıştır. Yollar gibi lineer karaktere sahip olan bu yeşil alanlar, merkezi rol üstlenen bütüncül yeşil ünitelerin birbirine bağlanmasında koridor olarak işlev görebilecek yapılardır. Bu bakımdan özellikle yol kenarı yeşil alanların tasarım ve planlama sürecinde, yeşil sistem içerisinde böylesine önemli bir sorumluluk üstlenebileceği bilinci ile hareket edilmesi gerekmektedir.

Yol kenarı yeşil alanlarla ilgili bulguların, bu karaktere sahip örnek bir alan üzerinde değerlendirilmesi, yeşil sistem içerisindeki rollerin tanımlanmasına katkı sağlayacaktır. $\mathrm{Bu}$ nedenle köprü yolu gibi ana bir artere Balmumcu Mahallesinde eşlik eden yeşil alan, daha kapsamlı olarak değerlendirilmiştir (Şekil 7).

Beşiktaş’ta doğu yönüne açık konumlarından ötürü köprülere bağlanan arterlerde rüzgâr koridoru oluşmaktadır. $\mathrm{Bu}$ konum bir yandan ilçe hava kalitesinin yükselmesine katkı sağlarken diğer yandan bu güzergahlara eşlik eden yeşil alanlar için olumsuz koşullar oluşturmaktadır. Halihazırda egzoz gazlarının etkisi altında olan bu alanlarda hem bu gazlara karşı toleranslı hem de rüzgâr etkisini tolere edebilecek türler tercih edilmelidir. Ancak olumlu bir etki olarak hava akımları, zararlı gazların yoğunlaşmasını da ertelemektedir. 

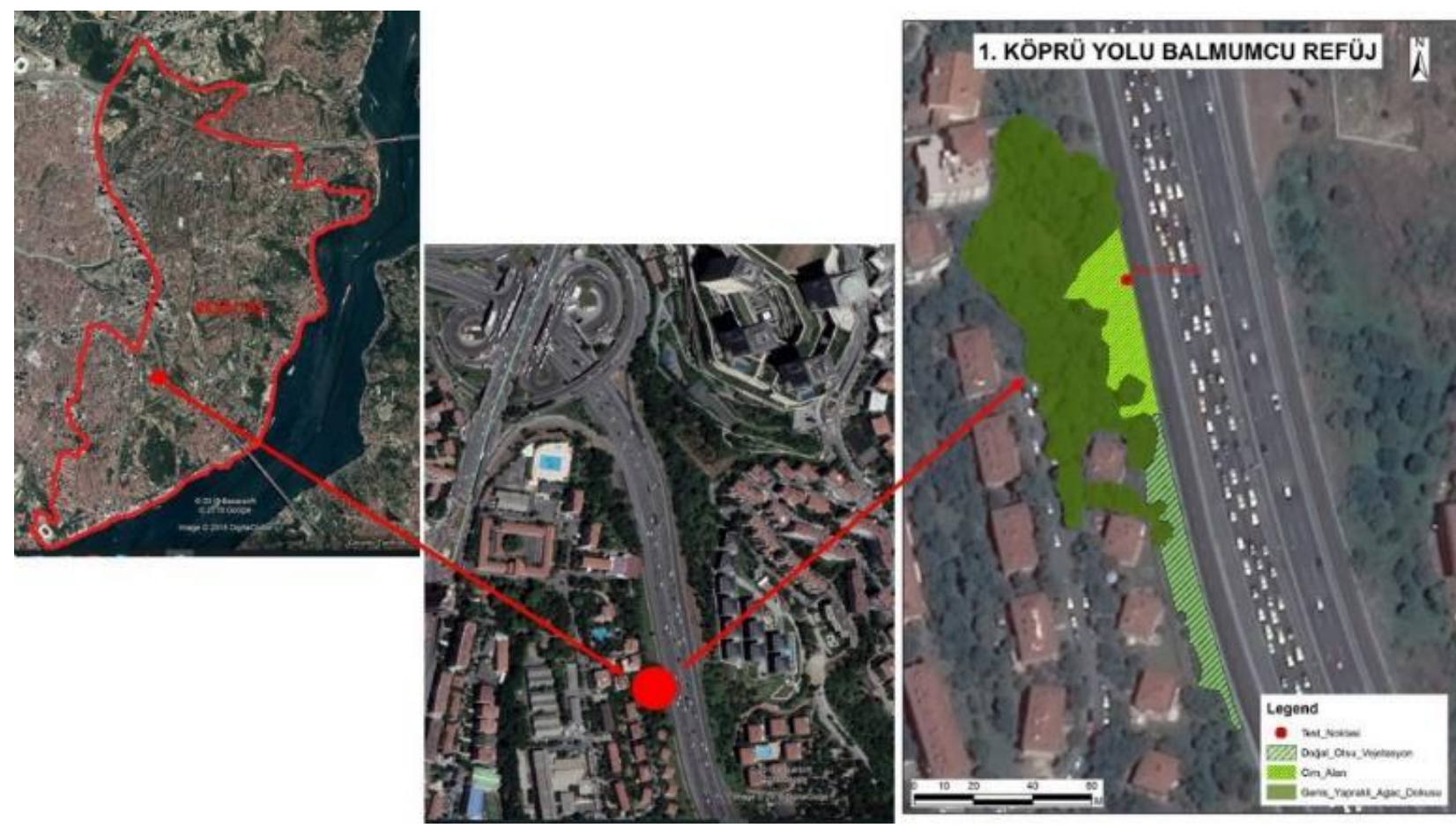

Şekil 7. Birinci köprü bağlantı yoluna eşlik eden yeşil alan (Balmumcu-Beşiktaş). (KAYNAK: Google Earth, 2018)

Balmumcu Yol Kenarı Yeşil alanının arka planında geniş yapraklı karma bir ağaç dokusu yer almaktadır (Şekil 8). Fakat bu doku, besin kaynağı açıssından zayıf bulunmuştur. Geniş yapraklı çalıların oluşturduğu seyrek bir alt doku mevcuttur. Ancak bu doku, yemiş veren doğal çalı gruplarından oluşmadığı için kuşlar için cazip değildir. Alanın açıklık, çim örtüsü ile kaplanmış kısımlarında kelebek türleri görülmemektedir.

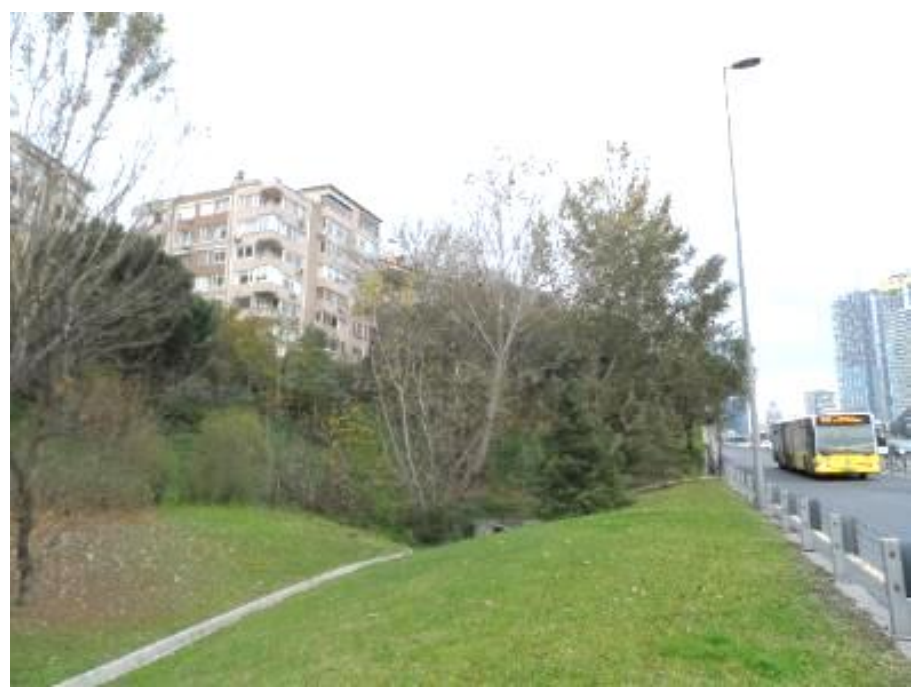

Şekil 8. Yeşil alanın odunsu bitki dokusu.

Yol kenarı yeşil alanlarda bakım ve sulama isteyen çim örtüsünün tercih edilmesi, biyoçeşitliliği de bloke eden bir unsur haline gelmektedir. Buna karşılık bakım ve sulama gerektiren çim alanın güneyinde, kendi haline bırakılmış olan patikada doğal otsu vejetasyonun baş göstermesine paralel olarak kelebek faunasının da çeşitlendiği dikkat çekmektedir (Şekil 9,10).

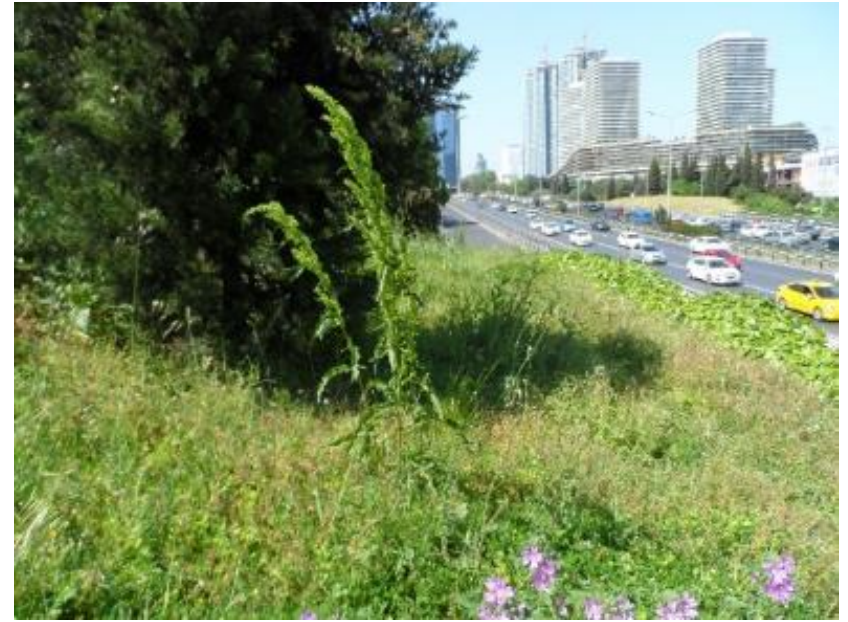

Şekil 9. Çim alanın güneyinde doğal vejetasyona terk edilmiş patika ve özellikle küçük kelebekler için önemli bir yaşama ortamı teşkil eden çiçekli otsu vejetasyon.

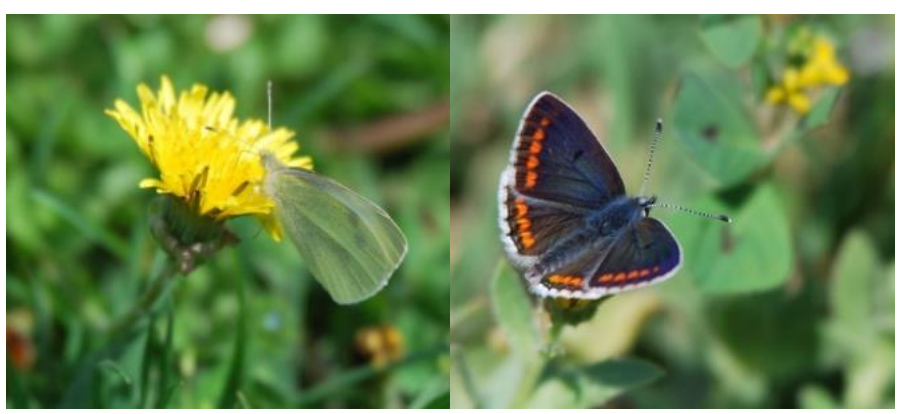

Sekil 10. Yol kenarl yeşil alanlarda çiçekli otsu vejetasyona sahip alanlarda kelebekler için olușan yașama ortamlarına örnekler.

Demir (2013)'in Beşiktaş İlçe Merkezi kapsamında gürültü düzeyleriyle ilgili yaptığı araştırmada, en yüksek ortalama gürültü düzeylerini ana yol güzergahlarının yakınında ölçmüştür. $\mathrm{Bu}$ araştırmaya göre Barbaros Bulvarı Zincirlikuyu Otobüs 
Durağ1 ortalama 79,55 dB, Akaretler Yokuşu ort. 75,48 dB, Beşiktaş Meydanı ort. 72,78 dB, ve Çırağan Caddesi ort. 70,12 $\mathrm{dB}$ gürültü düzeyine ulaşmaktadır.

Beşiktaş İlçesi kapsamında yürütülen araştırmanın bulgularına göre de ortalama gürültü düzeyinin $65 \mathrm{~dB}$ değerini aştığ1 noktalar, "Barbaros Bulvarı" ve "FSM Köprüsü Çevre Yolu Bağlantısı" olarak tespit edilmiştir. Bu değerlendirmelerden de anlaşılabileceği gibi kentsel bir peyzajda gürültü düzeyinin baskın rol oynadığı alanlar, ana yol arterleri ile yakından ilişkilidir.

Örnek alan olarak seçilen Balmumcu Yol Kenarı Yeşil alanında da ortalama $67,65 \mathrm{~dB}$ ses şiddeti ölçülmüştür. Beklendiği gibi alanın ilçeden geçen ana arterin bitişiğinde yer almasıyla bu alanda yaşayan canlıları en çok etkileyen faktörlerden birisi de gürültü olarak tespit edilmiştir. Bu bulguya bağlı olarak, gürültü ve emisyonun olumsuz etkisinin, yaşama ortamını kullanan canlı sayısını sınırlandırabileceği düşünülmüştür.

\subsection{Tartışma}

Turner, Gardner ve O’Neill (2001)'e göre; Peyzaj Ekolojisi, mekansal desenlerle ekolojik süreçler arasındaki etkileşim üzerinde durmaktadır. $\mathrm{Bu}$ nedenle mekansal desenlerin peyzaj metrikleriyle ölçülerek tanımlanması gerektiğini vurgulamaktadır. Leitão, Miller, Ahern ve McGarigal (2006), peyzaj metriklerini, peyzaj ekolojisi konularını planlamaya dahil etmek üzere kullanışlı ve temel araçlar olarak değerlendirmişler ve peyzaj metriklerinin, peyzaj bileşenlerinin hem zaman hem de mekân içerisindeki düzenlenişlerini ölçebilme özelliğinin, arazi plancıları ile yöneticilerine büyük umutlar vaat etiğini ifade etmişlerdir.

Sınıf ve peyzaj düzeyi metrik değerlendirmesinin yanı sıra, ayrıca test alanında gerçekleştiren yerinde gözlem ve ölçüm verilerinden elde edilen bulgular doğrultusunda, yeşil sistemin zamanla bozulmaya uğradığı ve bağlantısallık ilişkilerinin zayıfladığ1 görülmektedir. Bu bulgudan hareketle kentsel yeşil sistemlerde bağlantısallığı sağlayacak unsurların geliştirilmesinin ne kadar elzem olduğu anlaşılmaktadır. Yoğun kentleşme baskısı altında ve merkezi konuma sahip olan alanlarda özellikle yol ağlarının parçalayıcı etkisi dikkat çekmektedir. $\mathrm{Bu}$ nedenle çizgisel bariyerleri dengeleyebilecek olan yine çizgisel karakterde birimlere ihtiyaç duyulmaktadır. Bu ihtiyaca cevap verebilecek unsurların başında, yollara eşlik eden yeşil alanlar gelmektedir.

$\mathrm{Bu}$ araştırmada yol kenarı yeşil alanlar, yeşil sistemdeki konumları göz önünde bulundurularak, peyzaj strüktürü, peyzaj fonksiyonu, yaşama ortamı teşkil etme, trafik kontrolü ve estetik açılardan değerlendirilmiştir. Ayrıca kullanım ihtiyaçları da göz önünde bulundurularak "Kentsel Peyzaj Planlama ve Yönetim" kararlarına 1şık tutacak şekilde öneriler getirilmiştir.

\subsubsection{Peyzaj Fonksiyonu Açısından Yol Kenarı Yeşil Alanlar}

Hava akımlarının etkisiyle yol boyları, partikül maddenin de yoğun olarak etkili olduğu alanlardır. $\mathrm{Bu}$ nedenle özellikle odunsu ve herdemyeşil bitkilerin toz tutma potansiyelleri bu alanlarda önem kazanmaktadır (Şahin, 1989, s.61). Yol kenarı yeşil alanlar, doğru bir bitkisel tasarım ile araç yollarından kaynaklı emisyon, toz, gürültü gibi olumsuz etkileri absorbe etme özelliğine sahiptir (Nasrullah, Tatsumoto ve Misawa, 1994, s.328). Bu açıdan değerlendirildiğinde ana arterlere eşlik eden e-ISSN: 2148-2683 bu alanların, gürültü kontrolü açısından son derece önemli olduğu anlaşılmaktadır. Bu nedenle gerekli olan alanlarda, suni gürültü perdeleriyle birlikte tasarlanmaları gerekmektedir.

Beşiktaş’ta doğu yönüne açık konumlarından ötürü birinci ve ikinci köprü arterlerinde rüzgâr koridoru oluşmaktadır. $\mathrm{Bu}$ konum bir yandan ilçe hava kalitesinin yükselmesine katk1 sağlarken diğer yandan bu güzergahlara eşlik eden yeşil alanlar için olumsuz koşullar oluşturmaktadır.

Yapay topoğrafya oluşumları açısından değerlendirildiğinde yol kenarı yeşil alanlar, yapıların kat yüksekliğine bağlı olarak topoğrafyada meydana gelen ani iniş-çıkışlar arasında geçiş zonu oluşturma potansiyeline sahiptir. Öyle ki binalarla yollar arasında yer alan bu alanlarda tercih edilen özellikle odunsu karakterdeki bitkiler hem yükselti hem de doku bakımından tedrici bir geçiş sağlayarak rüzgâr koridoru, yüzeysel akış, 1S1 yoğunlaşmaları gibi olumsuz oluşumları dengeleyebilmektedir.

Kar yağışının olduğu günlerde buzlanmayı önlemek üzere yollarda yapılan tuzlama çalışmalarının da birincil etki alanı yine yol kenarı yeşil alanlardır. Ayrıca özellikle kış aylarında yol arterleri boyunca meydana gelen rüzgâr koridorlarının ekstrem dondurucu etkisinin de en çok hissedildiği alanlardır. $\mathrm{Bu}$ nedenlerle de yine tercih edilecek bitki türlerinin dayanıklı ve yöre şartlarına uyumlu olması önem kazanmaktadır.

\subsubsection{Peyzaj Strüktürü Açısından Yol Kenarı Yeşil Alanlar}

Peyzaj içerisinde yollar, habitatları parçalayan temel unsurlardandır. $\mathrm{Bu}$ nedenle hem kullanıcı güvenliği hem de biyoçeşitliliğin sağlanması için etkili bir şekilde planlanmaları ve yönetilmeleri gerekmektedir (Forman ve Deblinger, 2000, s.46). Elde edilen metrik bulguları, Beşiktaş İlçesi'nin 19632014 yılları arasındaki süreçte, peyzaj strüktürü bakımından doğaldan yapaya doğru hızlı bir dönüşüm içerisinde olduğunu göstermektedir. Yeşil doku parçalanmakta ve bütünlüğünü kaybetmektedir. Özellikle nüfus yoğunluğunun fazla olduğu güney batı mahallelerinde (Dikilitaş, Abbasağa, Gayrettepe, Türkali, Muradiye) Forman (1995)'ın tanımladığı fragmantasyon sürecinin etkileri yoğun olarak hissedilmekte ve yeşil doku, birbirinden kopuk küçük üniteler halini almaktadır. Araştırma Alanı'nda yollar \%23'lük yüzdeyle en fazla alan kaplayan yapılardır. Peyzaj strüktürü içerisinde çizgisel yapılarıyla yarılmalar şeklinde yeşil sistemi parçalayan yollar, başta popülasyon hareketi için bariyer teşkil etmektedir.

Kent ekosisteminde yollara eşlik eden yeşil alanlar da çizgisel karakterdeki elemanlardır. Bu özellikleriyle küme ya da ünite halindeki merkezi yeşil alanları bağlayıcı ve birbiriyle ilişkilendiren bir yapıya sahiptirler. Bu ilişkilerin kurulmasında araştırma alanında merkezi ünite teşkil etme potansiyeline sahip olan korular ve ev bahçeleri öncelikli olarak ele alınmalıdır. $\mathrm{Bu}$ yapılar arası bağlantısallığı kuvvetlendirecek her türlü tasarım ve planlama kararına öncelik tanınması, kent içi yeşil sistemin devamlılığı açısından büyük önem taşımaktadır.

Yeşil sistem içerisindeki bağlayıcı unsur olma özellikleri nedeniyle yol kenarı yeşil alanların tür hareketliliğini teşvik edecek besin, barınma, üreme ortamı teşkil etme gibi potansiyellere de sahip olmaları gerekir. Ayrıca bu potansiyeller, tasarım önceliği olarak da değerlendirilmelidir.

Dixon ve Wolf (2007)'a göre yol ağaçlandırmalarının, yol kenarı yeşil alanların lineer etkisini sürdürecek şekilde ele alınması ve salt estetik kaygılarla gerçekleştirilen bir yol 
ağaçlandırmasının yeşil alan sisteminin diğer unsurlarıyla ters düşmemesi gerekir.

\subsubsection{Yaşama Ortamı Olarak Yol Kenarı Yeşil Alanlar}

Refüjlerdeki yeşil dokunun otsu ya da odunsu karakterde olması, barındırdığı fauna grupları bakımından farklılık göstermektedir. Odunsu doku kuş ve yarasa gibi uçabilen türler için son derece önemlidir. Çiçek açan karma bir otsu vejetasyonun varlığı ise yaşamlarını sürdürmek üzere özellikle açıklıklara ihtiyaç duyan kelebekler için önem taşımaktadır (Şekil 10).

İstanbul İli, coğrafi konumu itibariyle çok çeşitli türlere ev sahipliği yapabilecek niteliktedir. Yollara eşlik eden yeşil alanlarda toz, tuzlama, emisyon, rüzgâr koridoru gibi olumsuz etkenler baskın olduğu için, bu alanlarda yer alacak bitkilerin yüksek bir dirence sahip olması gerekir. Bu nedenle adaptasyonu yüksek, doğal türler tercih edilmelidir. Bu yeşil alanlar kendi haline bırakıldığında, İstanbul'un zengin biyolojik çeşitliliği hemen kendini göstermektedir. Uçarak alana gelip çimlenen türlerden oluşan doğal otsu bir vejetasyon, kendiliğinden oluşabilmektedir (Şekil 9). Bu vejetasyonun oluşmasını teşvik edecek küçük müdahaleler dahi yol kenarı yeşil alanların, yaşam ortamı teşkil edecek şekilde kendini geliştirmesi açısından yeterli olacaktır.

Yol kenarı yeşil alanlarda tesviyeye bağlı olarak meydana gelen eğim nedeniyle erozyon probleminin oluşmaması için saçak köklü toprak tutucu odunsu bitkilerle takviyelerin yapılması yerinde bir karar olur. Bu türlerin de yine bakım isteği az, olumsuz koşullara karşı direnci yüksek nitelikte olması ve yaşama ortamı olarak refüjlerden yararlanan fauna gruplarına besin ve barınma imkânı sunması gerekir.

Yol kenarı yeşil alanları tasarlanırken, belli fauna gruplarına yaşama ortamı teşkil etme özelliği dikkate alınmadan, salt estetik unsurlar göz önünde bulundurularak yapılan bitki türü tercihlerinde, biyo-çeşitliliğgin hemen azaldığı tespit edilmiştir. Oysaki fauna grupları için yaşama ortamı teşkil etmeyen yol kenarı yeşil alanların, yeşil sistem içerisinde bağlayıcı ve tür hareketini teşvik edici fonksiyonlarını tam anlamıyla yerine getirebilmeleri de mümkün görünmemektedir.

Özellikle bakım isteyen (sulama, ot temizliği, havalandırma v.b.) çim sahaların tesis edilmesinin çok yönlü handikapları bulunmaktadır (Kırca ve Sevinç, 2020).

$\mathrm{Bu}$ sahalar hem tesisi hem de bakımı esnasında ekstra bir maliyet gerektirmektedir. Karma çim dokusu içerisinde çiçek açan türlerin yer almaması, kelebek, arı gibi türler açısından bir cazibe yaratmamaktadır. Bu türlerin bulunmadığ 1 alanlar kuşlar tarafından da tercih edilmemektedir. Ayrıca çim türleri, özellikle yüksek eğim derecelerinde erozyon önlenmesine nispeten düşük düzeyde katkı sağlayabilecek bir yapıya sahiptir.

Yollara eşlik eden yeşil alanlar uçamayan diğer türler, özellikle memeliler için tehlikeli olabilirler. Ancak kısıtlı bir ortamda yaşamını sürdüren sürüngenler için elverişli ortamlar oluşturularak bu alanlardaki biyolojik çeşitlilik arttırlabilir. Örneğin kot farklarını bağlamak üzere, derzlerinde kertenkele, böcek gibi birçok canlıya barınma imkânı sunan kuru taş duvarlar tercih edilebilir (Şekil 11).

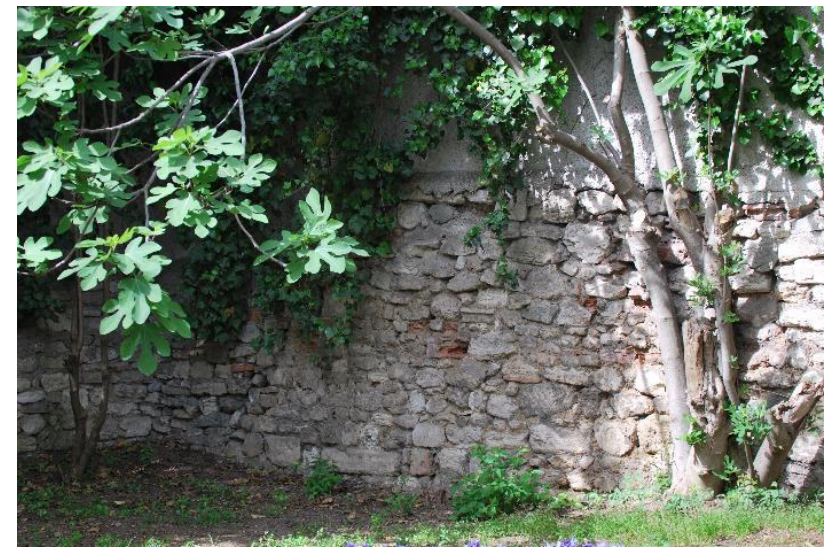

Şekil 11. Kuru taş duvarların derzleri kertenkele gibi sürüngenler için yaşama ortamı teşkil ederler.

Neticede yol kenarı yeşil alanlara dikilecek bitki türü tercihlerinin, hedef canlı gruplarına beslenme ve barınma imkânı sağlayabilecek nitelikte olmasına dikkat edilmesi, olabildiğince yemiş veren doğal türlerin kullanılması tavsiye edilmektedir.

Aynı şekilde bu gibi alanlarda yer alan yapısal donatıların (duvar, çit v.b.) malzeme tercihlerinde yaşama ortamı teşkil etme kriterlerine dikkat edilmesi, bilinçli tercihlerde bulunulması, kertenkele gibi başkaca türler için aynı zamanda barınma ve yaşama ortamı oluşturmak adına önem taşımaktadır.

\subsubsection{Trafik Kontrolü Açısından Yol Kenarı Yeşil Alanlar}

Yol kenarı yeşil alanların değerlendirilmesinde göz önünde bulundurulması gereken bir diğer önemli konu da ulaştırma yönetimi ve tasarımıdır. Bu alanlarda kullanılacak bitkiler, trafik seyrini aksatmayacak ve yönlendirecek niteliklere de sahip olmalıdır. Özellikle ulaşım ağlarının yoğun ve işlek olduğu kentsel peyzajlarda, refüjlerin trafik kontrolü açısından önemi daha da artmaktadır (Şekil 12).

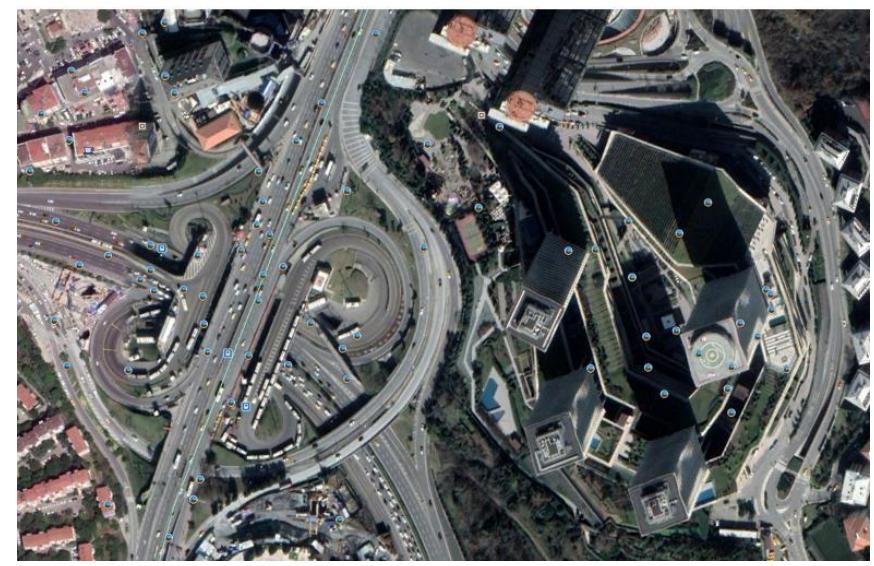

Şekil 12. Zincirlikuyu Kavşağı ve eşlik eden yeşil alanlar. (KAYNAK: Google Earth, 2020)

\subsubsection{Estetik Açıdan Yol Kenarı Yeşil Alanlar}

Özellikle yoğun ulaşım ağlarına sahip büyük şehirlerde bu yollara eşlik eden yeşil alanlar, aynı zamanda şehrin imaj unsurlarıdır. Yoğun trafik akışı sırasında belli bir güzergâh boyunca görsel algıya hitap eden bu alanların, aynı zamanda estetik unsurları da barındırması gerekir. Ancak bu estetik algının kent imajını destekleyen odunsu bitkilerle üçüncü boyuta taşınması bu alanların hem fonksiyonel ve ekolojik görevlerini karşılar, hem de kimlikli bir yapı kazandırmak suretiyle estetik algıyı destekler. 
Kent ekosistemi açısından değerlendirildiğinde estetik kaygılar, fonksiyonel özellikleri yansıtabilme potansiyelinin önüne geçmemelidir. Estetik yaklaşımların fonksiyonel yapıyı destekleyici nitelikte olması gerekir. Fazla bakım isteyen, olumsuz etkilere karşı direnci nispeten zayıf olan bitki türleri, salt estetik kaygılarla tercih edilmemelidir. Estetik yapıyı destekleyen tasarımlarda, özellikle tür seçiminde ekolojik döngüleri destekleyen, fauna grupları için yaşama ortamı teşkil eden bitki türlerine ağırlık verilmelidir.

\subsubsection{Yol Kenarı Düzenlemelerinde Yeşil Cephe Sistemleri ve Dikey Bahçeler}

Peyzaj yüzdesi bulguları incelendiğinde, yol ağlarının \%23'lük bir yüzdeyle araştırma alanında en baskın sınıf olduğu görülmektedir. Buna karşılık yollara eşlik eden yeşil alanların yüzdesi sadece $\% 5$ 'lik bir oranda kalmaktadır. Bu bulgu, yolların kent içindeki olumsuz etkilerini kıracak nitelikteki yeşil alanların yetersizliğini göstermektedir. Bu nedenle günümüzde gündemde olan yeşil duvar, dikey bahçe gibi sistemler, ekolojik ve fonksiyonel anlamda büyük önem taşımaktadır. Ancak güncel uygulamalar incelendiğinde bu tür sistemlerde kent ekosistemini desteklemek, yeşil sistemde bağlayıcı bir fonksiyon üstenmek gibi vazifelerin ötesinde tasarım kaygısının daha çok estetik olduğu görülmektedir. Özellikle yol ağlarına eşlik edebilecek yeşil alanlar için pay olmayan kısımlarda; yol ağlarının yerleşim, ticaret, sanayi amaçlı kullanım mekanlarına doğrudan komşu olduğu alanlarda, yeşil sistemin bağlayıcılık görevini üstlenebilecek alternatif sistemlere ihtiyaç duyulmaktadır. Bu tip alanlarda nispeten dar bir alanda tesis edilebilen dikey bahçe ve yeşil cephe gibi sistemler, olabildiğince yol kenarı yeşil alanların rollerini üstlenebilecek nitelikte tasarlanmalıdır. Aksi taktirde oldukça masraflı olabilen bu sistemler, bol sulamaya ve bakıma ihtiyaç duyan, egzotik ve kısa ömürlü bitki türleri kullanılarak tesis edilirse yeşil sistemin desteklenmesine ve ekolojik anlamda görevler üstlenmek adına yetersiz kalacaktır. Ancak sürdürülebilir bir sistem algısıyla, ekosistem mantığı içerisinde kurgulanan yeşil cephe sistemleri ve dikey bahçeler, özellikle yolların kenarında yeşil alan tesis edecek pay bulunmayan kısımlarda yeşil sistemi sürdüren hayati bir görev üstlenebilirler.

\section{Sonuç}

Özellikle kentsel peyzajlarda yol ağlarına eşlik eden yeşil alanlar, kent ekosisteminin hem fonksiyonel hem strüktürel anlamda önemli bileşenleridir.

Test alanında yapılan gözlemler, egzotik türlerle yapılan ve çiçek açan tür sayısı az olan bitkilendirmelerde, doğal haline terk edilmiş ve doğal çiçek açan otsu vejetasyona sahip alanlara kıyasla fauna çeşitliliğinin azaldığını göstermiştir. Buna karşılık doğal otsu vejetasyonun görüldüğü alanlarda özellikle kelebek faunasııın da çeşitlendiği dikkat çekmiştir. Odunsu dokuda ise yenebilen yemiş veren türlerin yer almasıyla birlikte böcek ve kuş türlerinin çeşitlendiği görülmüştür.

Özellikle ana arterlere eşlik eden yeşil alanların gürültü, toz, emisyon, tuzlanma, rüzgâr koridoru gibi olumsuz etkilere maruz kalması, bu etkilere karşı toleransı yüksek bitki türlerinin tercih edilmesini gerektirmektedir. Bu olumsuz etkiler zaten bu yaşama ortamını kullanan canlı sayısını sınırlandırmaktadır. Bu nedenle refüj alanlarında dikilecek bitki türü tercihi yapıllırken hiç değilse hedef canlı gruplarına beslenme ve barınma imkânı sağlayabilecek nitelikte olmasına dikkat edilmelidir. Olabildiğince yemiş veren doğal türler kullanılmalıdır.
$\mathrm{Bu}$ gibi alanlarda yer alan istinat duvarları sarmaşıklarla sardırıldığında kuşlar ve sürüngenler için yaşama ortamı teşkil edebilir. Ayrıca yapı malzemesi tercihinde de yaşama ortamı teşkil etme kriterine dikkat edilmelidir.

Bitkilerin peyzaj için sağladıkları fonksiyonel ve ekolojik fayda, biyo-kütleleri ile doğru orantılıdır. Özellikle yol kenarı yeşil alanlarda salt estetik kaygılarla bakıma muhtaç çim alanların çalılara ve ağaçlara tercih ediliyor olması, bu fonksiyonel yaklaşımla çelişmektedir. Gerek biyo-çeşitliliği artırmak gerekse sağladıkları oksijen miktarı ve havayı filtreleme kapasiteleri bakımından odunsu bitkiler tercih edilmelidir. Yaşama ortamı teşkil etmesi bakımından otsu doku farklı fauna gruplarına hizmet etmektedir ve bu çeşitlik için de ortam oluşturulmalıdır ancak bu dokunun da kendi haline terk edilmiş, farklı ve çiçek açan otsu türleri barındıran doğal bir yapıda olması tercih edilmeli ve mutlaka odunsu doku ile birlikte çözümlenmelidir.

Alansal olarak büyüklükleri göz önünde bulundurulduğunda yol kenarı yeşil alanlarda, sulama ve bakım ihtiyacı duyan çim alanların ve mevsimlik bitki parterlerinin tesis edilmesi, maliyeti arttıran bir tercihtir.

Nitelikli bir refüj ve yol ağaçlandırması, öncelikle peyzaj strüktüründe yeşil sisteme sağlayacağ ve peyzaj fonksiyonu açısından kent ekosistemini destekleyici özellikler açısından ele alınmalıdır. Refüjlerin trafik kontrolüne engel olmayacak, aksine destekleyecek bir karakterde olması gerekir. Estetik kaygılar, yukarıda bahsedilen öncelikli yaklaşımlarla birlikte ele alınmalı ve değerlendirilmelidir.

\section{Özetle:}

- Çizgisel karakterdeki yapıları dolayısıyla yol kenarı yeşil alanlar, yeşil sistem içerisinde yer alan ve kentleşme baskısıyla adacıklar şeklinde izole olmuş merkezi konumdaki yeşil üniteleri bağlayabilecek, birbirleriyle ilişkilendirebilecek nitelikte çok önemli bir rol üstlenirler. Planlama ve tasarım kararları alınırken, kent ekosistemi içerisinde yol kenarı yeşil alanların bu önemli fonksiyonuna öncelik verilmelidir.

- Yol kenarı yeşil alanların gürültü-toz-emisyon-tuzlanma gibi olumsuz etkileri absorbe edebilecek karakteristiklere sahip olmaları gerekir.

- Rüzgâr ve gürültüyü perdeleyebilecek türlerle tesis edilmeleri gerekir.

- Eğim yüksekse erozyonu engelleyecek karakterde tasarlanmalıdırlar.

- Belli fauna grupları için yaşama ortamı teşkil etmelidirler.

- Popülasyon hareketini destekleyebilmeleri için çevresel faktörlere karşı direnci yüksek olan doğal türlerden oluşmalıdırlar.

- Asgari düzeyde bakım ihtiyacı duyan doğal odunsu ve otsu türler tercih edilmelidir.

- Trafik yönetimini destekleyici nitelikte olmalıdırlar.

- Yol kenarında alan yetersizliği nedeniyle sekteye uğradıkları kısımlarda, sürdürülebilirlik kriterleri ve ekosistem algısıyla kurgulanmış dikey bahçe ve yeşil cephe gibi sistemlerle desteklenmeleri gerekmektedir. 
- Kent kimliğini yansıtacak estetik unsurları da barındırmalıdırlar.

\section{Kaynakça}

Ahern, J. (2004). Greenways in the USA: Theory, Trends and Prospects. In: Ecological Networks and Greenways Concept, Design, Implementation. Pp 34-55. Ed: Jongman, R.H.G. ve Pungetti, G., Cambridge University Press, UK. ISBN: 0521 535026

Bentrup, G. (2008). Conservation buffers. Design Guidelines for Buffers, Corridors, and Greenways. Gen. Tech. Rep. SRS-109. Asheville, NC: Department of Agriculture, Forest Service, Southern Research Station.

Çepel, N. (1994). Peyzaj Ekolojisi Ders Kitabı. İstanbul Üniversitesi Yayınları, Üniversite Yayın No: 3868, Fakülte Yayın No: 429 Orman Fakültesi, İstanbul ISBN: 975-404-371-X

Çepel, N. (2003). Ekolojik Sorunlar ve Çözümleri. TÜBİTAK Popüler Bilim Kitapları 180, Ankara. ISBN: 975-403-290-4

Çepel, N. (2006). Ekoloji, Doğal Yaşam Dünyaları ve İnsan. Palme Yayıncılık, Ankara, ISBN: 975-8982-68-0.

Darmstad, W.E., Olson, J.D., Forman, R.T.T. (1996). Landscape Ecology Principles in Landscape Architecture an Land-use Planning. Harward University Graduate School of Design, Island Press, American Society of Landscape Architects. U.S.A., ISBN: 1-55963-514-2.

Demir, S. (2013). İstanbul'un Beşiktaş İlçe Merkezinde Gürültü Düzeyleri Belirlenerek Gürültü Haritasının Oluşturulması. Doktora Tezi. Marmara Üniversitesi, Sağlık Bilimleri Enstitüsü, Halksağlığı Anabilim Dalı, İstanbul.

Dixon, K.K. ve Wolf, K.L. (2007). Benefits and Risks of Urban Roadside Landscape: Finding a Livable, Balanced Response. Proceedings of the 3rd Urban Street Symposium (June 24-27, 2007; Seattle, WA). Washington D.C.: Transportation Research Board of the National Academies of Science.

Erell, E., Pearlmutter, D., Williamson, T. (2011). Urban Microclimate. Designing the Spaces Between Buildings. Earthscan from Routlege, Taylor \& Francis, London. ISBN: 978-1-84407-467-9

Farina, A. (1998). Principles and Methods in Landscape Ecology. Chapman \& Hall, UK ISBN: 0412730405 (PB).

Forman, R.T.T. (1995). Land Mosaics. New York: Cambridge University Press., U.K., ISBN: 978-0-521-479980-6 (PB).

Forman, R.T.T. (2008). Urban Regions. Ecology and Planning Beyond the City. Cambridge University Press, UK., ISBN-13: 978-0-521-67076-0 (PB).

Forman, R.T.T. (2014). Urban ecology: science of cities. UK: Cambridge University Press. ISBN: 978-0-521-18824-1 (PB).

Forman, R.T.T. ve Deblinger, R.D. (2000). The Ecological RoadEffect Zone of a Massachusetts (U.S.A.) Suburban Highway. Conservation Biology, Vol. 14, No. 1, Pages 36-46.

Forman R. T. T. ve Godron M. (1986), Landscape Ecology. John Wiley \& Sons. New York, ISBN: 0-471-87037-4.

Gartland, L. (2008). Heat Islands: Understanding and Mitigating Heat in Urban Areas. Earthscan, UK. ISBN-13: 978-1-84407250-7.

Hellmund, P.C. ve Smith, D.S. (2006). Designing Greenways. Sustainable Landscapes for Nature and People. Island Press, Washington, 2006. ISBN: 1-55963-329-8

Hergül, Ö.C. ve Göker, P. (2020). Evaluating Eco-Cities With A Sustainable Perspective In Human-Nature Interaction. European Journal of Science and Technology, (21), 561-567.

Jongman, R.H.G. (2004). The Context and Concept of Ecological Networks. Pp 7-33 In: Ecological Networks and Greenways Concept, Design, Implementation. Ed: Jongman, R.H.G. ve
Pungetti, G., Cambridge University Press, UK. ISBN: 0521 535026

Jongman, R.H.G. ve Pungetti, G. (2004). Introduction: Ecological Networks and Greenways. Pp 1-6 In: Ecological Networks and Greenways Concept, Design, Implementation. Ed: Jongman, R.H.G. ve Pungetti, G., Cambridge University Press, UK. ISBN: 0521535026

Kırca, S., Altınçekiç H., Levin, N. 2015. Landscape Continuity Analysis as a Tool for Landscape Planning: A Case Study in Istanbul, Landscape Research, 40(3): 359-376.

Kırca, S., Sevinç, Ş. (2020) Kentlerde Etkin Doğa Koruma İçin Yol Kenarlarındaki Çim Alanlar Üzerine Bir Değerlendirme. Peyzaj Araştırmaları ve Uygulamaları Dergisi (PAUD), 2(2): 51-60.

Kuttler, W. (2008). The Urban Climate - Basic and Applied Aspects. In: Urban Ecology, an International Perspective on the Interaction Between Humans and Nature, ed: Marzluff, J.M., Shulenberger, E., Endlicher, W., Alberti, M., Bradley, G., Ryan, C., Simon, U., ZumBrunnen, C., Springer Science+Business Media, Pp: 233-248, LLC, NY. USA, ISBN: 978-0-387-734118.

Leitão, A.B., Miller, J., Ahern, J., McGarigal, K. (2006). Measuring Landscapes. A Planner's Handbook. Island Press, U.S.A., ISBN: 1-55963-899-0 (PB).

McGarigal, K. (2002). Landscape pattern metrics. In: El-Shaarawi, A.H., Pieporsch, W.W. (eds.), Encyclopedia of Environmetrics, 2. John Wiley \& Sons, Chichester, England, Pp. 1135-1142, ISBN: 0-471-89997-6.

McGarigal, K., Cushman, S.A., Ene, E. (2015). FRAGSTATS v4: Spatial Pattern Analysis Program for Categorical and Continuous Maps. Computer software program produced by the authors at the University of Massachusetts, Amherst.

Musaoğlu, N., Coşkun, M.Z., Göksel, Ç., Kaya, Ş., Bektaş, F., Saroğlu, E., Üstün, B., İpbüker, C., Erden, T., Karaman, H. (2004). İstanbul Anadolu Yakası Hazine Arazilerinin Uydu Verileri ve Coğrafi Bilgi Sistemleri (CBS) ile İncelenmesi. TÜBİTAK-İnşaat ve Çevre Teknolojileri Araştırma Grubu (IÇTAG-I433) Proje Raporu, Proje No: 103I011

Nasrullah, N., Tatsumoto, H., Misawa, A. (1994). Effect of Roadside Planting and Road Structure on No2 Concentration Near Road. Jpn. J. Toxicol. Environ. Health, 40 (4), 328-337.

Oke, T.R. (1976). The Distinction Between Canopy and Boundary-layer Urban Heat Islands. Atmosphere, 14:4, 268277, DOI: 10.1080/00046973.1976.9648422

Rees, W. ve Wackernagel, M. (2008). "Urban Ecological Footprints: Why Cities Cannot be Sustainable - and Why They are a Key to Sustainability", ed: Marzluff, J.M., Shulenberger, E., Endlicher, W., Alberti, M., Bradley, G., Ryan, C., Simon, U., ZumBrunnen, C., Springer Science+Business Media, Pp: 537555, LLC, NY. USA, ISBN: 978-0-387-73411-8, 2008.

Suri, L. 2018. "Search for Plans for Drinking Water Basins: Ömerli Drinking Water Basin as an Example," Journal of Multidisciplinary Research (1947-2900), 1(1), 0-0

Suri, L. 2019. Kentsel Alanlarda Barınma Sorunları ve Çözüm Arayışı, ISAS WINTER-2019, Kasım, 4th International Symposium on Innovative Approaches in Architecture, Planning and Design Samsun / Turkey

Şahin, Ş. 1989. Ankara kenti yol ağaçlarının sorunları ve peyzaj mimarlığı açısından alınması gerekli önlemler. Ankara Üniversitesi Fen Bilimleri Enstitüsü Yüksek Lisans Tezi, 372s, Ankara.

Turner, M., Gardner, R.H., O’Neill, R.V. (2001). Landscape Ecology. In Theory and Practice, Pattern and Process, Springer Verlag, NY, USA. ISBN: 0-387-95123-7

Türkiye İstatistik Kurumu (TÜIK), (2017). Adrese Dayalı Nüfus Kayıt Sistemi Sonuçları., (https://biruni.tuik.gov.tr/ ziyaret tarihi: 10.11.2018) 